\title{
Untersuchungen zur Rolle von Klf10 und Klf11 \\ als Mediatoren von NGF- und TGF- $\beta$-vermittelten Effekten in Zellen neuraler Herkunft
}

\author{
Dissertation \\ zur Erlangung des Doktorgrades \\ der Fakultät für Agrarwissenschaften \\ der Georg-August-Universität Göttingen
}

vorgelegt von

Gabriele Spittau

Göttingen, 2011 
D7

1. Referent: Prof. Dr. Dr. Bertram Brenig

2. Referent: Prof. Dr. Christoph Knorr

Tag der mündlichen Prüfung: 17.11.2011 


\section{Danksagung}

Als erstes möchte ich mich bei Frau Professor Dr. Krieglstein für die Bereitstellung des Promotionsthemas, für die vielen hilfreichen Anregungen und für die freundliche Unterstützung während der Zeit meiner Doktorarbeit bedanken. Für die externe Betreuung, die hilfreichen Ratschläge und die Übernahme des Referates möchte ich mich bei Professor Dr. Dr. Bertram Brenig bedanken.

Bei allen Kolleginnen und Kollegen der Abteilung Neuroanatomie in Göttingen möchte ich mich für die herzliche freundschaftliche Aufnahme in die Abteilung, den Kollegialen Zusammenhalt, die Hilfsbereitschaft und die netten Abende im Sausalitos bedanken. Ganz besonders möchte ich Ivo dafür danken, dass er während meiner Schwangerschaft die Dinge im Labor für mich erledigt hat, die ich selber nicht mehr machen durfte, und Marion für ihren unermüdlichen Einsatz als Babysitter, für fleißiges Korrekturlesen und für ihre Dienste als „Briefträger“. Helmut danke ich für seine hilfsbereite und geduldige Unterstützung bei den auch dieses Mal wieder unvermeidlichen „Computerproblemen“.

Ein ganz besonderer Dank gilt natürlich meinen Eltern. Ohne Ihre Unterstützung wäre das „Projekt Doktorarbeit“ unmöglich gewesen.

Zuletzt möchte ich mich den drei wichtigsten Menschen an meiner Seite danken, Björn für die fachliche und persönliche Unterstützung, die Aufmunterung und das unermüdliche Korrekturlesen und Henner und Marja Mootje dafür, dass sie mein Leben unendlich bereichert haben, auch wenn sich dadurch die Fertigstellung der Doktorarbeit ein wenig verzögert hat. 


\section{Liste der Publikationen und Posterpräsentationen}

Die vorliegende Arbeit basiert auf den durch Fettdruck hervorgehobenen Publikationen und Posterabstracts:

\section{Publikationen:}

1. Kämper M.R., Gohla G. and Schlüter G. (2002). A novel positive tetracyclinedependent transactivator (rtTA) variant with reduced background activity and enhanced activation potential. FEBS Letters, 517(1-3), 115-120.

2. Lacmann A., Hess D., Gohla G., Roussa E. and Krieglstein K. (2007). Activity-dependent release of transforming growth factor-beta in a neuronal network in vitro. Neuroscience, 150(3), 647-657.

3. Gohla, G., Krieglstein, K. and Spittau, B. (2008). Tieg3/Klf11 induces apoptosis in OLI-neu cells and enhances the TGF-beta signaling pathway by transcriptional repression of Smad7. Journal of Cellular Biochemistry, 104(3), 850-861.

4. Spittau, G., Happel, N., Behrendt, M., Chao, T. I., Krieglstein, K. and Spittau, B. (2010). Tieg1/KIf10 is upregulated by NGF and attenuates cell cycle progression in the pheochromocytoma cell line PC12. Journal of Neuroscience Research, 88(9), 2017-2025.

\section{Posterpräsentationen}

Die Abstracts zu den Postern (mit Ausnahme von Poster Nr. 2) sind unter den folgenden Internetadressen zu finden:

http://www.anatomische-gesellschaft.de/annual-meetings/abstract archive.html

\section{http://anatomische-gesellschaft.de/annual-workshops-arbeitstagung.html}

1. Gohla, G., Behrendt, M., Roussa, E. and Krieglstein, K. (2006). NGF-mediated transcriptional Regulation of Klf10 and Klf11. Zusammenfassung aller Vortragsund Posterabstracts der 23. Arbeitstagung der anatomischen Gesellschaft in Würzburg vom 27.09. - 29.09.2006, Poster 87.

2. Gohla, G., Behrendt, M. and Krieglstein, K., The role of Klf10 and Klf11 in NGF-mediated survival and differentiation of PC12 cells. Poster Abstract Booklet, 101st Annual Meeting, Freiburg 2006

3. Gohla, G., Spittau, B., Behrendt, M. and Krieglstein, K. Tieg1/Klf10 contributes to NGF-mediated cell cycle arrest of PC12 cells by regulation of p21. Poster Abstract Booklet, 103 ${ }^{\text {rd }}$ Annual Meeting, Innsbruck 2008, 167.

4. Spittau, B., Gohla, G. and Krieglstein, K., 103. Jahresverammlung der anatomischen Gesellschaft, Innsbruck 2008. Tieg3/Klf11 modulates TGF-beta signaling by transcriptional silencing of the inhibitory Smad7. Poster Abstract Booklet, $103^{\text {rd }}$ Annual Meeting, 168. 


\section{Verzeichnis der verwendeten Abkürzungen}

ActRI/ActRIB

AIF

ALK

Apaf1

ATP

$\mathrm{Bad}$

Bax

Bcl-2

Bcl- $X_{\mathrm{L}}$

Bcl-w

Bid

Bik

Bim

BH1-4

Blk

Bmf

BMP

BMPRIA

BNIP3

Bok

Caspase

CDK

CGNP

CHO-Zellen

CHX

C. elegans

co-Smad

CREB

CTGF

Cys

DNA

DR-4 bzw. -5
Activin Receptor1/Activin Receptor1B

apoptosis inducig factor

Activin receptor like kinase

apoptotic protease activating factor 1

Adenosintriphosphat

Bcl-2/BclX associated death promoter

Bcl-2 associated $\underline{X}$ protein

B-Cell Lymphoma Gene $\underline{2}$

B-Cell Lymphoma Gene extra long

$\underline{B}-\underline{C}$ ll Lymphoma Gene $\underline{w}$

$\underline{B}$ cl-2-like inducer of death

Bcl-2 interacting killer

Bcl-2 interacting mediator of cell death

$\underline{B} \mathrm{cl} 2$ homology domain $\underline{1}-\underline{4}$

Bik like killer protein

Bcl-2 modifying factor

Bone morphogenic protein

$\underline{B M P}-\underline{R} e c e p t o r \underline{1 A}$

Bcl-2 Adenovirus E1B 19-KD Protein interacting Protein 3

$\underline{B} \mathrm{cl}-2$ related ovarian killer protein

cysteine-dependent aspartate-specific protease

cyline dependent kinase

Cerebellar granular neuronal precurser

Chinese hamster ovary-Zellen

Cycloheximide

$\underline{\text { Caenorrhabditis elegans }}$

common mediator Smad

cAMP resonse-element binding protein

connecting tissue growth factor

Cystein

Desoxyribonucleic acid

death receptor-4 bzw. -5 


\begin{tabular}{|c|c|}
\hline $\mathrm{EGR} \alpha$ & Early growth response gene alpha \\
\hline Elov16 & elongation of very long-chain fatty acid-like \\
\hline 6ERK & extracellular signal regulated kinase \\
\hline Fas/CD95 & Fibroblast associated-receptor/CD95-receptor \\
\hline Fas & Fatty acid synthase \\
\hline FADD & Fas-asssociated via death domain \\
\hline FGF & $\underline{\text { Fibroblast growth factor }}$ \\
\hline GDNF & 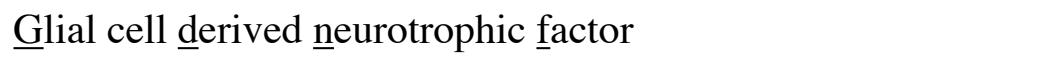 \\
\hline GTPasen & Guanintriphosphat spaltende Enzyme \\
\hline His & $\underline{\text { Histidin }}$ \\
\hline Hrk & Harakiri \\
\hline I-Smads & inhibitory-Smads \\
\hline Klf & 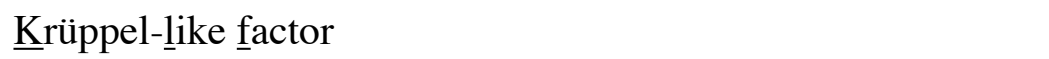 \\
\hline Ko & Knockout \\
\hline MH1 und MH2 & 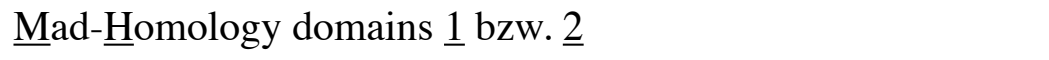 \\
\hline mGIF & $\underline{\text { murine }} \underline{\mathrm{GDNF}}$ inducible factor \\
\hline MAO B & 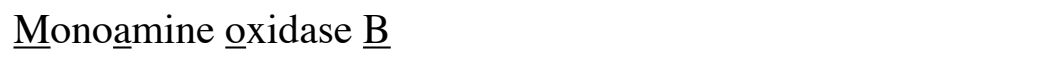 \\
\hline MAPKs & 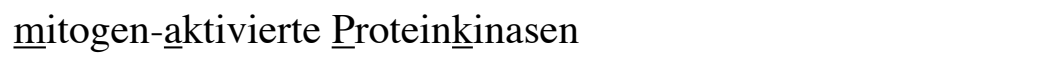 \\
\hline Mcl-1 & Induced myeloid leukemia cell differentiation protein \\
\hline MPF & $\underline{\text { mitosis-promoting factor }}$ \\
\hline NGF & $\underline{\text { Nerve growth factor }}$ \\
\hline NLS & 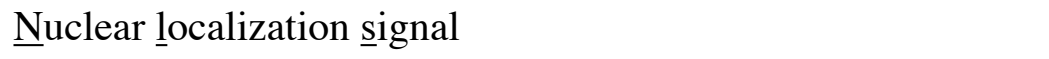 \\
\hline Noxa & Mediator of hypoxic cell death \\
\hline $\mathrm{p} 21$ & cycline dependent kinase inhibitor \\
\hline Pepck & Phosphoenyl-pyruvate-carboxykinase \\
\hline Pttg1 & $\underline{\text { Pituitary tumor-transforming gene-1 }}$ \\
\hline Puma & p53 activated mediator of apoptosis \\
\hline SID & m $\underline{S}$ in $3 \mathrm{~A}$ interacting domain \\
\hline siRNA & $\underline{\text { small }}$ inhibitory $\underline{\mathrm{R} N A}$ \\
\hline \multirow[t]{2}{*}{ Smac/DIABLO } & 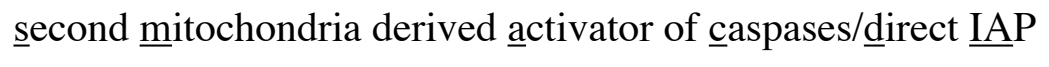 \\
\hline & binding protein with $\underline{\text { low }} \mathrm{pI}$ \\
\hline Smad & 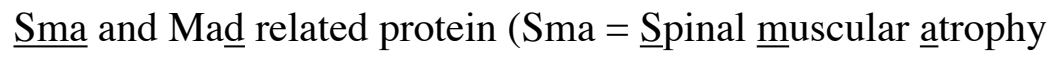 \\
\hline and & 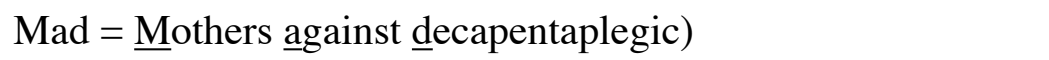 \\
\hline
\end{tabular}


specificity protein 1

Spike

small protein with inherent killing effect

Srebp1c

sterol regulatory element binding protein $1 \mathrm{c}$

RNA

Ribonucleic acid

R-Smads

receptor associated $\underline{\text { Smads }}$

RhoA

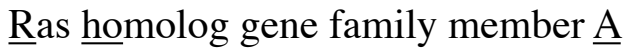

$\mathrm{T} \beta \mathrm{RI} / \mathrm{T} \beta \mathrm{RII}$

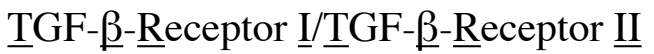

TFIIIA

transcriptionfactor IIIA

TrkA/TrkB/TrkC

tropomyosin-related $\underline{\text { kinase }} \underline{\mathrm{A}} / \underline{\mathrm{B}} / \underline{\mathrm{C}}$

TGF- $\beta$

Transforming growth factor- $\underline{\beta}$

$\mathrm{T}$

Thymin

Tieg

TGF- $\beta$ inducible early response gene

TNFR-1

tumor necrosis factor receptor- $\underline{1}$

TRAIL

$\underline{T N F-r e l a t e d ~ a p o p t o s i s ~ i n d u c i n g ~ l i g a n d ~ r e c e p t o r ~}$

$\mathrm{ZF}$

zincfinger 


\section{Abbildungs- und Tabellenverzeichnis}

\section{Verzeichnis der verwendeten Abbildung}

$\begin{array}{llc}\text { Abbildung } & \text { Titel } & \text { Seite } \\ \text { Abbildung 1 } & \text { Die Expression der Zykline im Verlauf des Zellzyklus } & 3 \\ \text { Abbildung 2 } & \text { Die Regulation von Proliferation, Apoptose und } & 6 \\ & \text { Differenzierung durch Wachstumsfaktoren } & 8 \\ \text { Abbildung 3 } & \text { Neurotrophine und ihre Rezeptoren } & 10 \\ \text { Abbildung 4 } & \text { Der NGF-Signalweg } & 13 \\ \text { Abbildung 5 } & \text { Der Smad-abhängige TGF- } \beta \text {-Signalweg } & 14 \\ \text { Abbildung 6 } & \text { Übersicht über die Smad Proteine } & 15 \\ \text { Abbildung 7 } & \text { Strukturelle Eigenschaften der Sp1- und } & \end{array}$

Abbildung 7 Die Rolle von Klf11 bei der TGF- $\beta$-vermittelten 27

Apoptose

\section{Tabellenverzeichnis}

Tabelle Titel

Tabelle 1

Synonyme der Transkriptionsfaktoren Klf10 und Klf11

Tabelle 2

Die Stationen des Zellzyklus

Tabelle 3

Die Aktivierung der CDKs in den verschiedenen Phasen des Zellzyklus

Tabelle 4 TypI- und TypII-Rezeptoren der TGF- $\beta$-Familie,

Liganden und korrespondierende Smads

Tabelle 5 


\section{Vorwort zur Nomenklatur von Klf10 und Kfl11}

Da die Nomenklatur im Falle von Klf10 bzw. Klf11 nicht ganz eindeutig ist und zahlreiche Synonyme in der Literatur zu finden sind, wird an dieser Stelle in tabellarischer Form darauf hingewiesen, welche Termini im folgenden Text verwendet werden, was sie bedeuten und welche Synonyme in der Literatur vorliegen. Im vorliegenden Text werden weiterhin groß geschriebene Buchstaben wie z.B. KLF10 und KLF11 jeweils für die humanen Isoformen der Proteine verwendet, während mit Klf10 und Klf11 in den meisten Fällen die murinen Isoformen, gelegentlich auch die der Ratte gemeint sind. Kursiv geschrieben Buchstaben, Klf10 und Klf11, bzw. KLF10 und KLF11 beschreiben die Verwendung von Genen.

Tabelle 1: Synonyme der Transkriptionsfaktoren Klf10 und Klf11 in den verschiedenen Spezies, die genomische Lokalisation und die Bedeutung der verwendeten Synonyme (Tabelle modifiziert nach Spittau und Krieglstein, 2012)

\begin{tabular}{|c|c|c|}
\hline $\begin{array}{l}\text { Symbol/ } \\
\text { Bedeutung }\end{array}$ & Synonyme/Bedeutung & $\begin{array}{l}\text { Spezies/ } \\
\text { Lokalisation }\end{array}$ \\
\hline $\begin{array}{l}\text { Klf10/ } \\
\text { Krüppel-like factor } 10\end{array}$ & $\begin{array}{l}\text { AI115143 } \\
\text { EGRa = Early growth response gene alpha (Splicevariante von Klf10) } \\
\text { Egral }=\text { Early growth response gene alpha } 1 \\
\text { Gdnfif }=\text { GDNF inducible factor } \\
\text { mGIF = murine GDNF inducible factor } \\
\text { Tieg }=\text { TGF- } \beta \text { inducible early response gene } \\
\text { Tieg1 = TGF- } \beta \text { inducible early response gene } 1\end{array}$ & $\begin{array}{l}\text { Mus musculus/ } \\
\text { Chromosom } 15\end{array}$ \\
\hline $\begin{array}{l}\text { KLF10/ } \\
\text { Krüppel-like factor } 10\end{array}$ & $\begin{array}{l}\text { EGRA }=\text { Early growth response gene alpha } \\
\text { TIEG = TGF- } \beta \text { inducible early response gene } \\
\text { TIEG1 = TGF- } \beta \text { inducible early response gene } 1\end{array}$ & $\begin{array}{l}\text { Homo sapiens/ } \\
\text { Chromosom } 8\end{array}$ \\
\hline $\begin{array}{l}\text { KIf10/ } \\
\text { Krüppel-like factor } 10\end{array}$ & TIEG $=$ TGF $-\beta$ inducible early response gene & $\begin{array}{l}\text { Rattus norvegicus/ } \\
\text { Chromosom } 7\end{array}$ \\
\hline $\begin{array}{l}\text { Klf11/ } \\
\text { Krüppel-like factor } 11\end{array}$ & $\begin{array}{l}\text { 9830142A17 } \\
\text { D12Ertd427e } \\
\text { Tieg2 = TGF- } \beta \text { inducible early response gene } 2 \\
\text { Tieg2b = TGF- } \beta \text { inducible early response gene } 2 \text { b } \\
\text { Tieg3 = murine Isoform von Tieg2 bzw. Klf11 }\end{array}$ & $\begin{array}{l}\text { Mus musculus/ } \\
\text { Chromosom } 12\end{array}$ \\
\hline $\begin{array}{l}\text { KLF11/ } \\
\text { Krüppel-like factor } 11\end{array}$ & $\begin{array}{l}\text { FKLF = fetal Krüppel-like factor } \\
\text { FKLF1 = fetal Krüppel-like factor } 1 \\
\text { MODY7 = Maturity onset diabetes of the young } 7 \\
\text { TIEG2 = TGF- } \beta \text { inducible early response gene } 2 \\
\text { Tieg3 = TGF- } \beta \text { inducible early response gene } 3\end{array}$ & $\begin{array}{l}\text { Homo sapiens/ } \\
\text { Chromosom } 2\end{array}$ \\
\hline $\begin{array}{l}\text { KIf11/ } \\
\text { Krüppel-like factor } 11\end{array}$ & Tcfcp212 & $\begin{array}{l}\text { Rattus norvegicus/ } \\
\text { Chromosom } 6\end{array}$ \\
\hline
\end{tabular}




\section{Inhaltsverzeichnis}

I. Danksagung

II. Liste der Publikationen und Posterpräsentationen

III. Abkürzungsverzeichnis

IV. Abildungs- und Tabellenverzeichnis

V. Vorwort zur Nomenklatur

VI. Inhaltsverzeichnis

1. Einleitung

2. Untersuchungen zur Rolle von Klf10 und Klf11 als Mediatoren von NGFund TGF- $\beta$-vermittelten Effekten $\quad 2$

2.1. Der Zellzyklus 2

2.2. Der generelle Mechanismus der Apoptose 4

2.3. Wachstumsfaktoren 5

2.3.1. Die Neurotrophine und der Nervenwachstumsfaktor NGF 6

2.3.1.1. Die Rezeptoren der Neurotrophine $\quad 7$

2.3.1.2. Der NGF-Signalweg 9

2.3.2. Die TGF- $\beta$-Familie und ihre Funktionen 11

2.3.2.1. Die TGF- $\beta$-Rezeptoren 11

2.3.2.2. Der TGF $\beta$-Signalweg 12

2.3.2.3. Die Rolle der Smads im TGF- $\beta$-Signalweg 13

2.4. Transkriptionsfaktoren 14

2.4.1. Die Familie der SP1- und Krüppelähnlichen Transkriptionsfaktoren 15

2.4.2. Die Transkriptionsfaktoren Klf10 und Klf11 16

2.4.3. Die strukturellen Eigenschaften von Klf10 und Klf11 16

2.4.4. Die Expression von Klf10 und Klf11 18

2.4.5. Die Induktion von Klf10 und Klf11 18

2.4.6. Die antiproliferative Wirkung von Klf10 und Klf11 19

2.4.7. Die proapoptotische Wirkung von Klf10 und Klf11 20

2.4.8. Die Klf10- und Klf11-Knockout-Mäuse 21

2.5. Die Auswahl der Zelllinien Oli-neu und PC12 23

2.6. Darstellung des Forschungsprojektes und Zielsetzung der vorliegenden Arbeit...... $\quad 23$

2.7. Diskussion und Ausblick 25

2.7.1. Die Rolle von Klf11 bei der TGF- $\beta$-vermittelten Apoptose 25 
2.7.2. Die Expression und Regulation von Klf10 und Klf11 in PC12-Zellen 28

2.7.3. Die Rolle von Klf10 bei der NGF-vermittelten Differenzierung 29

3. Literaturverzeichnis 31

4. Abstract $\quad 42$

5. Zusammenfassung 43

6. Anhang 44 


\section{Einleitung}

Bei der ontogenetischen Entwicklung aller Gewebe spielen aufeinander abgestimmte Vorgänge, wie Proliferation, Differenzierung und Apoptose eine wesentliche Rolle. Hierzu gibt es laut Cook und Urrutia (2000) die folgende allgemeine Arbeitshypothese: Um Vorgänge wie Proliferation, Differenzierung und Apoptose zu regulieren, muss die Zelle extrazelluläre Signale aufnehmen und zu einem „Genexpressionsprogramm“ umwandeln. Dies erfolgt meist durch die Initiation einer Signalkaskade über die Bindung eines Liganden an einen Rezeptor. Diese resultiert in posttranslationellen Modifikationen von intrazellulären Proteinen der Zelloberfläche, welche entweder zu kurzfristigen Reaktionen, wie z.B. der Reorganisation des Zytoskeletts, oder zu langfristigeren Reaktionen, wie z.B. Zellwachstum, Differenzierung oder Apoptose führen. Für die langfristigen Reaktionen kann das Signal vom Zytoplasma in den Kern übertragen werden, in dem Transkriptionsfaktoren aktiviert werden. Die aktivierten Transkriptionsfaktoren können nun ihrerseits die Expression von Genen aktivieren oder hemmen. Die Regulation von Zellwachstum, Differenzierung oder Apoptose hängt somit vom geordneten Zusammenspiel zellulärer Signalwege und der transkriptionellen Regulation der Gene ab (Cook und Urrutia, 2000). Zu den wohl bedeutendsten Regulatoren in diesem Zusammenhang gehören sowohl die Neurotrophine mit ihrem „Gründungsmitglied“, dem Nerven-Wachstumsfaktor NGF, als auch die Mitglieder der Familie der Transformierenden Wachstumsfaktoren (TGF- $\beta$-Superfamilie). Die „Krüppel-ähnlichen Faktoren“ wiederum gehören zu den Transkriptionsfaktoren, die durch Neurotrophine oder Mitglieder der TGF- $\beta$-Superfamilie reguliert werden können. Klf10 und Klf11 waren ursprünglich als TGF- $\beta$-induzierbare Gene beschrieben worden. Durch intensive Forschung in den letzten Jahren konnte gezeigt werden, dass nicht nur unterschiedliche Mitglieder der TGF- $\beta$-Familie, sondern vielmehr auch zahlreiche andere Faktoren in der Lage sind, die Mitglieder der sogenannten „TiegFamilie“Apoptose und der Zellzykluskontrolle spielen. Die vorliegende Arbeit beschäftigt sich mit der Rolle der Transkriptionsfaktoren Klf10 und Klf11 in diesem Kontext, mit besonderem Fokus auf neurale Zellsysteme. 


\section{Untersuchungen zur Rolle von KIf10 und KIf11 als Mediatoren von NGF- und}

TGF- $\beta$-vermittelten Effekten in Zellen neuraler Herkunft

\subsection{Der Zellzyklus}

Der Zellzyklus beschreibt eine Reihe von zellulären Ereignissen, die in einer eukaryotischen Zelle im Verlauf von einer Zellteilung zur nächsten stattfinden. Das Wachstum, die Reparatur und die Erhaltung von Organismen sind abhängig von einem geregelten Verlauf des Zellzyklus. Defekte in der Regulation sind der Ursprung einer Vielzahl von Erkrankungen, sowie die Ursache neoplastischer Transformationen. Der Zellzyklus unterteilt sich im Regelfall in Mitose und Interphase. Letztere ist die längste Phase im Zellzyklus. Sie kann ihrerseits in drei Phasen unterteilt werden: Die G1-, die S und die G2-Phase, dabei steht das „G-“ in der G1- und der G2-Phase für „growth“ = Wachstum und das „S“ für Synthese. Die Stationen des Zellzyklus werden in Tabelle 2 beschrieben (Gomperts et al., 2003).

Tabelle 2: Die Stationen des Zellzyklus (Tabelle modifiziert nach „Signal Transduction“ von Gomperts et al., 2003)

\begin{tabular}{lll}
\hline Phasen: & Ereignisse: \\
\hline Interphase & G1 & $\begin{array}{l}\text { Im Anschluss an die Zellteilung. DNA-Integrität, Zellgröße, Kern-Plasma } \\
\text { Verhältnis und das Vorhandensein von „Baustoffen“ und Wachstumsfaktoren wird } \\
\text { überprüft. Vorbereitung auf die Synthesephase. }\end{array}$ \\
& G0 & $\begin{array}{l}\text { Gelegentlich Übergang in eine postmitotische Ruhephase in der auch differenzierte } \\
\text { Zellen verharren. }\end{array}$ \\
& G & Replikation der DNA. \\
& G2 & $\begin{array}{l}\text { Integrität der Replikation wird überprüft. Vorbereitung auf die Mitose durch } \\
\text { verstärkte Synthese zellteilungsspezifischer Proteine. }\end{array}$ \\
\hline Mitose & M $\quad \begin{array}{l}\text { Zellteilung, lässt sich wiederum unterteilen in Prophase, Prometaphase, Metaphase } \\
\text { Anaphase und Telophase. }\end{array}$ \\
\hline
\end{tabular}

Der Zellzyklus wird durch verschiedene äußere und innere Faktoren beeinflusst. Zu den äußeren Faktoren gehören z.B. die Zellgröße, das zur Verfügung stehende Nährstoffangebot oder die Anzahl der Nachbarzellen. Auch künstliche Faktoren oder Substanzen wie z.B. Desoxythymidin oder Aphidicolin können den Zellzyklus beeinflussen. Im Verlauf der Zellteilung gibt es mehrere Kontrollpunkte, die sogenannten „Checkpoints“, welche Steuerungsmechanismen darstellen, die die Dauer und Abfolge der Phasen kontrollieren und dafür sorgen, dass zuerst ein Abschnitt 
vollständig abgeschlossen wird, bevor der nächste Schritt der Zellteilung erfolgt. An diesen Punkten besteht die

Möglichkeit einer Unterbrechung des Zellzyklus oder der Einleitung des kontrollierten Zelltodes (Apoptose). Die Abfolge von Ereignissen, die schließlich in der Zellteilung gipfelt, kann zu einem großen Teil mit der sequenziellen Expression von Zyklinen erklärt werden (s. Abbildung 1).

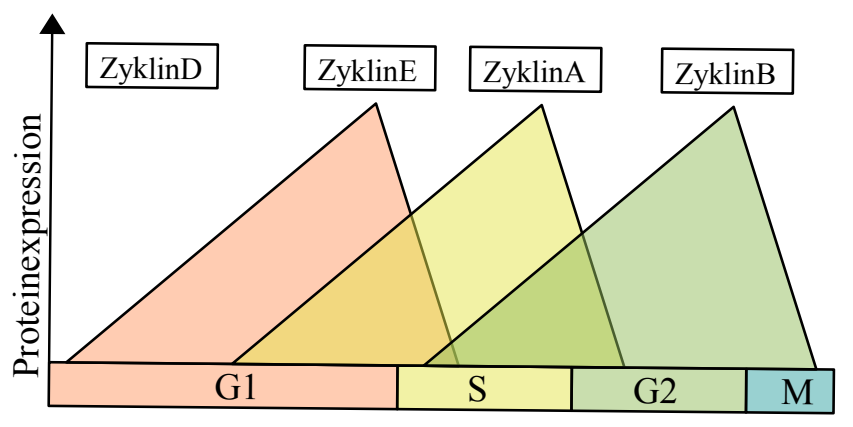

Abbildung 1: Die Expression der Zykline im Verlauf des Zellzyklus (Abbildung modifiziert nach „Signal Transduction“ von Gomperts et al., 2003).

Diese Proteine initiieren einerseits die fortlaufenden Phasen des Zellzyklus und sind andererseits am Abbruch der vollendeten Phasen beteiligt. Sie üben ihre Handlung durch die Aktivierung von bzw. die Verbindung mit den Zyklin abhängigen

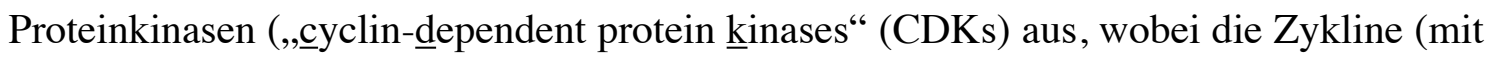
Ausnahme von ZyklinD) zyklisch exprimiert werden. Ihre Expressionsmaxima stellen vermutlich Kontrollpunkte dar. Nach ihrer maximalen Expression werden sie rasch abgebaut. Im Gegensatz zu den Zyklinen sind die CDKs ständig präsent. Die Zellteilung wird durch die Bildung des ,"mitose promoting factor“ (MPF) eingeleitet, welcher von einem Proteinkomplex aus ZyklinB und CDK1 gebildet wird. Das Prinzip der Aktivierung der CDK durch ein spezifisches Zyklin findet man in allen Zellzyklusphasen (s. Tabelle 3) (Gomperts et al., 2003).

Tabelle 3: Die Aktivierung der CDHs in den verschiedenen Phasen des Zellzyklus (Tabelle modifiziert nach ,Signal Transduction“" von Gomperts et al., 2003)

\begin{tabular}{ll}
\hline Phase & Zyklin/CDK-Komplex \\
\hline Frühe G1-Phase & ZyklinD/CDK4 und CDK6 \\
Späte G1-Phase & ZyklinE/CDK2 \\
S-Phase & ZyklinA/CDK2 \\
Späte S-Phase und S/G2-Übergang & ZyklinA/CDK1 \\
G2-Phase und G2/M-Übergang & ZyklinB/CDK \\
\hline
\end{tabular}




\subsection{Der generelle Mechanismus der Apoptose}

Die Anzahl der Zellen in einem Organismus wird durch eine fein abgestimmte Balance zwischen Zellwachstum und Zelltod aufrechterhalten. Der 1964 eingeführte Begriff „programmierter Zelltod“, auch Apoptose genannt, beschreibt einen Prozess, der sowohl während der Embryonalentwicklung als auch bei der Erhaltung von adulten Geweben eine bedeutende Rolle spielt. Er wird durch eine kontrollierte Abfolge von Ereignissen reguliert, die letztendlich zu einer Selbstzerstörung der Zellen führen (Lockshin und Williams, 1964). Ein Teil der Veränderungen apoptotischer Zellen werden durch die sogenannten Caspasen verursacht. Der Begriff Caspase ist aus „cysteine-dependent aspartate-specific protease“ zusammengesetzt. Die Caspasen sind Bestandteil einer großen Proteinfamilie, deren katalytische Aktivität von einem Cysteinrest innerhalb eines hoch konservierten Pentapeptids abhängt.

Bei der Initiierung des programmierten Zelltods unterscheidet man einen extrinsischen von einem intrinsischen Weg. Der extrinisische Weg zeichnet sich durch die Bindung von spezifischen Liganden an bestimmte Membranproteine und anschließender Aktivierung dieser sog. „Todesrezeptoren“ aus. Die wichtigsten Rezeptoren für den extrinsischen Weg sind der TNFR-1 (,,tumor necrosis factor receptor 1“), Fas/CD95 und die TRAIL (,TNF-related apoptosis inducing ligand receptor“)-Rezeptoren DR-4 (,death receptor“) und DR-5 (Ashkenazi, 2002). Nach Aktivierung der Rezeptoren durch die Bindung eines Liganden bilden die Rezeptoren zunächst ein Homotrimer (Naismith und Sprang, 1998). Für die weitere Signalübertragung sind die zytosolischen Domänen der Rezeptoren zuständig, die mit Hilfe von FADD (,,Fas-asssociated via death domain“), einem Adaptermolekül, die Procaspase-8 rekrutieren. Es kommt daraufhin zu einer lokalen Ansammlung dieser inaktiven Form der Caspase-8, die in einer autolytischen Aktivierung von Procaspase-8 zu Caspase- 8 und der anschließenden proteolytischen Spaltung und Aktivierung von Procaspase-3 zu Caspase-3 resultiert. Diese spalten daraufhin spezifische Substrate innerhalb der Zelle, wodurch es zur Apoptose kommt.

Beim intrinsischen Weg spielen Faktoren wie z.B. DNA-Schädigung, oxidativer Stress oder chemotherapeutische Wirkstoffe eine Rolle (Kaufmann und Earnshaw, 2000; Wang, 2001). Diese Faktoren führen zum Zusammenbruch des Membranpotentials der inneren Mitochondrienmembran, wodurch diese durchlässig wird. Es kommt zum Einströmen von Wasser und in Folge dessen zum Anschwellen der Mitochondrien. 
Erreichen diese eine kritische Größe, zerreißt die äußere Membran, wodurch proapoptotische Proteine, wie z.B. ZytochromC, der ,apoptosis inducing factor“ AIF (Susin et al., 1999), die Endonuklease endoG (Li et al. 2001) sowie Smac/DIABLO (Verhagen et al., 2000) in das Zytosol gelangen (Bernadi et al. 1999, Loeffler und Kroemer 2000). Durch das Zytochrom C, wird das sog. Apoptosom aktiviert.

Eine Verbindung zwischen dem extrinsischen und dem intrinsischen Weg wird durch das Protein Bid dargestellt, welches zur Familie der Bcl-2-Proteine gehört. Bcl-2Proteine werden nach dem Vorhandensein konservierter Motive, den sog. „B $\underline{\text { cl-2 }}$ homology domains“ $\mathrm{BH} 1-\mathrm{BH} 4$, in eine antiapoptotische und eine proapoptotische Gruppe unterteilt. Die Mitglieder der antiapoptotischen Gruppe besitzen die Domänen $\mathrm{BH} 1, \mathrm{BH} 2, \mathrm{BH} 3$ und BH4. Zu ihnen gehört außer Bcl-2 unter anderem auch Bcl-X $\mathrm{L}$ Die proapoptotische Gruppe wird in zwei weitere Untergruppen aufgeteilt: die Bax-Familie mit den Domänen BH1, BH2 und BH3 sowie die Familie der „BH3-only“-Proteine die nur über eine kurze BH3-Domäne verfügen (Hengartner, 2000). Zur Bax-Familie gehören unter anderem Bax und Bak. Einige der Mitglieder der „BH3-only“-Gruppe sind z.B. Bid, Bim und Bad. Bid wird durch Caspase- 8 gespalten, transloziert zu den Mitochondrien und vermittelt dort mit Hilfe von Bax und Bak die Freisetzung von ZytochromC (Luo et al. 1998). Dieses bindet im Zytosol an das Protein Apaf-1 (,,apoptotic protease activating factor 1“), welches unter Verbrauch von ATP seine Konformation verändert. Insgesamt sieben Apaf-1/ZytochromC-Komplexe formen nun gemeinsam das Apoptosom, welches die Aktivierung von Caspase-9 fördert (Acehan et al., 2002). Daraufhin wird eine Caspase-Kaskade aktiviert und es kommt zur Aktivierung der sog. Effektorcaspasen Caspase-3, Caspase-6 und Caspase-7 und in der Folge zum apoptotischen Zelltod (Slee et al. 1999).

\subsection{Wachstumsfaktoren}

Für die Regulation von Proliferation, Differenzierung und Apoptose müssen die Zellen extrazelluläre Signale aufnehmen und mit Hilfe von Wachstumsfaktoren zu einem „Genexpressionsprogramm“ umwandeln. Durch die Wachstumsfaktoren wird eine Signalkaskade initiiert, welche die Aktivierung von Transkriptionsfaktoren nach sich zieht. Diese können nun ihrerseits die Expression von Genen aktivieren oder hemmen. Die Regulation von Zellwachstum, Differenzierung oder Apoptose hängt somit von 
einem geordneten Zusammenspiel zellulärer Signalwege und der transkriptionellen Regulation von Genen ab (s. Abbildung 2) (Cook und Urrutia, 2000).

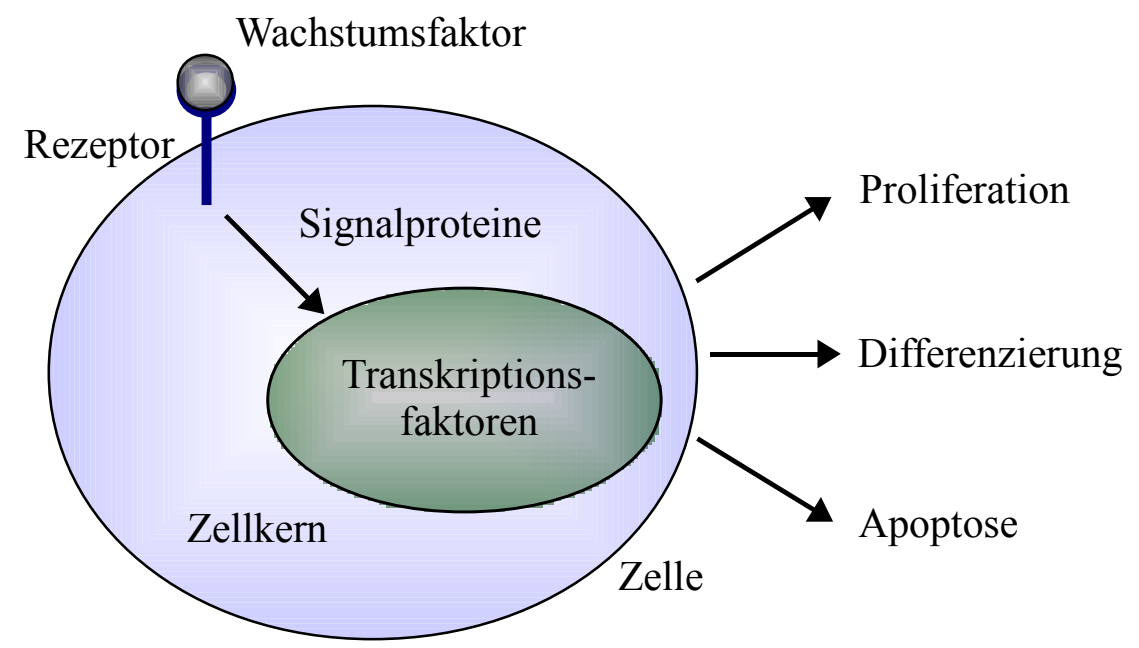

Abbildung 2: Die Regulation von Proliferation, Differenzierung und Apoptose durch Wachstumsfaktoren. Ein Wachstumsfaktor bindet an einen Rezeptor und setzt eine Signalkaskade in Gang. Dadurch werden Transkriptionsfaktoren aktiviert, welche Vorgänge wie Zellwachstum, Differenzierung und Apoptose regulieren (Abbildung modifiziert nach Cook und Urrutia, 2000).

\subsubsection{Die Neurotrophine und der Nerven-Wachstumsfaktor NGF}

Mit der Entdeckung des Nerven-Wachstumsfaktors (Nerve growth factor) NGF vor fast 60 Jahren durch Rita Levi-Montalchini wurde nicht nur das Gründungsmitglied einer neuen Familie von Proteinen entdeckt, die bei der Entwicklung des Nervensystems von Wirbeltieren eine essentielle Rolle spielen, sondern der erste Wachstumsfaktor überhaupt. Für diese Entdeckung wurde Rita Levi Montalcini 1986 gemeinsam mit Stanley Cohen mit dem Nobelpreis für Medizin ausgezeichnet. Die Isolierung von NGF gelang zunächst aus der Glandula submandibularis der Maus (Levi-Montalcini, 1987). Der Faktor setzt sich aus drei Untereinheiten, $\alpha$ - , $\beta$ - und $\gamma$-NGF zusammen, wobei $\beta$ NGF, dessen Isolierung erstmals Scott et al. (1983) und Ullrich et al. (1983) gelang, die am meisten untersuchte Untereinheit darstellt. Es handelt sich dabei um ein 12,5 kDA schweres Protein, das die protektiven sowie die wachstumsfördernden Funktionen von NGF besitzt. Es lässt sich in zwei identische Ketten von jeweils 118 Aminosäurren spalten. Sowohl Monomer als auch Dimer sind biologisch aktiv (Frazier et al., 1973; Stach und Shooter, 1974). Die zwei $\gamma$-Untereinheiten des NGF Komplexes besitzen eine proteolytische Aktivität (Greene et al., 1969), während die Funktion der $\alpha$-Untereinheit bisher nicht vollständig geklärt ist. Es wird angenommen, dass Letztere $\beta$-NGF vor der 
Proteolyse schützt und somit die biologische Aktivität reguliert. In vivo wird NGF als Prä-Pro-Protein translatiert, wobei die 18 Aminsosäuren große Prä-Sequenz bei der Translokation ins endoplasmatische Retikulum abgespalten wird (Berger und Shooter, 1977; Ullrich et al., 1983). Pro-NGF wird dann, ebenso wie die anderen Neurotrophine an seiner hoch konservierten dibasischen „Teilungsstelle“ durch Furin oder die sog. ProConvertasen zu „reifem“ NGF gespalten (Barde 1990).

\subsubsection{Die Rezeptoren der Neurotrophine}

Die Aktionen der Neurotrophine hängen hauptsächlich von zwei unterschiedlichen Transmembran-Rezeptorsystemen ab: den Trk Rezeptor Tyrosin Kinasen TrkA, TrkB und TrkC und dem p75-ㅌeurotrophin ㅈezeptor (p75 NTR). Zusätzlich interagieren sie mit einer Reihe von Membranproteinen und erweitern durch diese Promiskuität ihr funktionelles Repertoire beträchtlich (Huang und Reichhardt, 2003). Der zuerst entdeckte Trk Rezeptor, TrkA, wurde mit Hilfe von Gentransferassays an einem Karzinom isoliert. Bei der Klonierung zeigte sich, dass er aus den ersten sieben von acht Exons des nichtmuskulären Tropomyosins, gekoppelt an die transmembranen und zytoplasmatischen Domänen einer neuen Tyrosinkinase besteht und wurde somit als „,tropomyosin related kinase“ betitelt. Die Gene für $\operatorname{TrkB}$ sowie $\operatorname{TrkC}$ wurden später aufgrund ihrer Homologie zu TrkA entdeckt. Die in Abbildung 3 dargestellten TrkRezeptoren zeigen unterschiedliche Bindungspezifitäten für die verschiedenen Neurotrophine, welche hauptsächlich durch die zellmembrannahen IgG-ähnlichen Domänen bestimmt werden (Windisch et al., 1995). Diese Interaktionen werden im Allgemeinen als Interaktionen hoher Affinität bezeichnet, tatsächlich jedoch sind die Affinitäten von NGF zu TrkA sowie von BDNF zu TrkB nicht besonders stark, können jedoch durch Rezeptor Dimerisierung, strukturelle Modifikationen sowie durch die Expression des Neurotrophinrezeptors p75 ${ }^{\mathrm{NTR}}$ erhöht werden. Bei p75 $5^{\mathrm{NTR}}$ handelt es

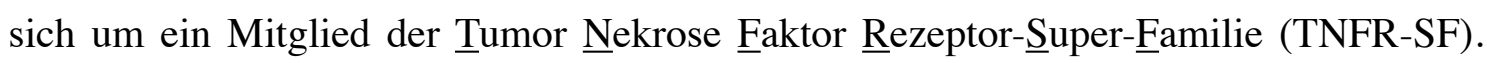
Wird er mit den Trk-Rezeptoren koexprimiert bildet er mit diesen Komplexe, wodurch sich die Signaltransduktion beider Partner verändert (Huang und Reichardt, 2003). TrkRezeptoren gehen vorzugsweise Verbindungen mit den reifen Neurotrophinen ein, während die Pro-Neurotrophine bevorzugt an den p75 seinerseits einen Komplex mit Sortilin bildet (Nykjaer et al., 2004). NGF aktiviert, ebenso wie die anderen Neurotrophine, die Rezeptoren dieser zwei unterschiedlichen 
Klassen (Martin-Zanca et al., 1989; Chao et al., 1986) und ist dadurch in der Lage, so unterschiedliche Vorgänge wie Überleben, Differenzierung, Wachstum und Apoptose zu vermitteln.

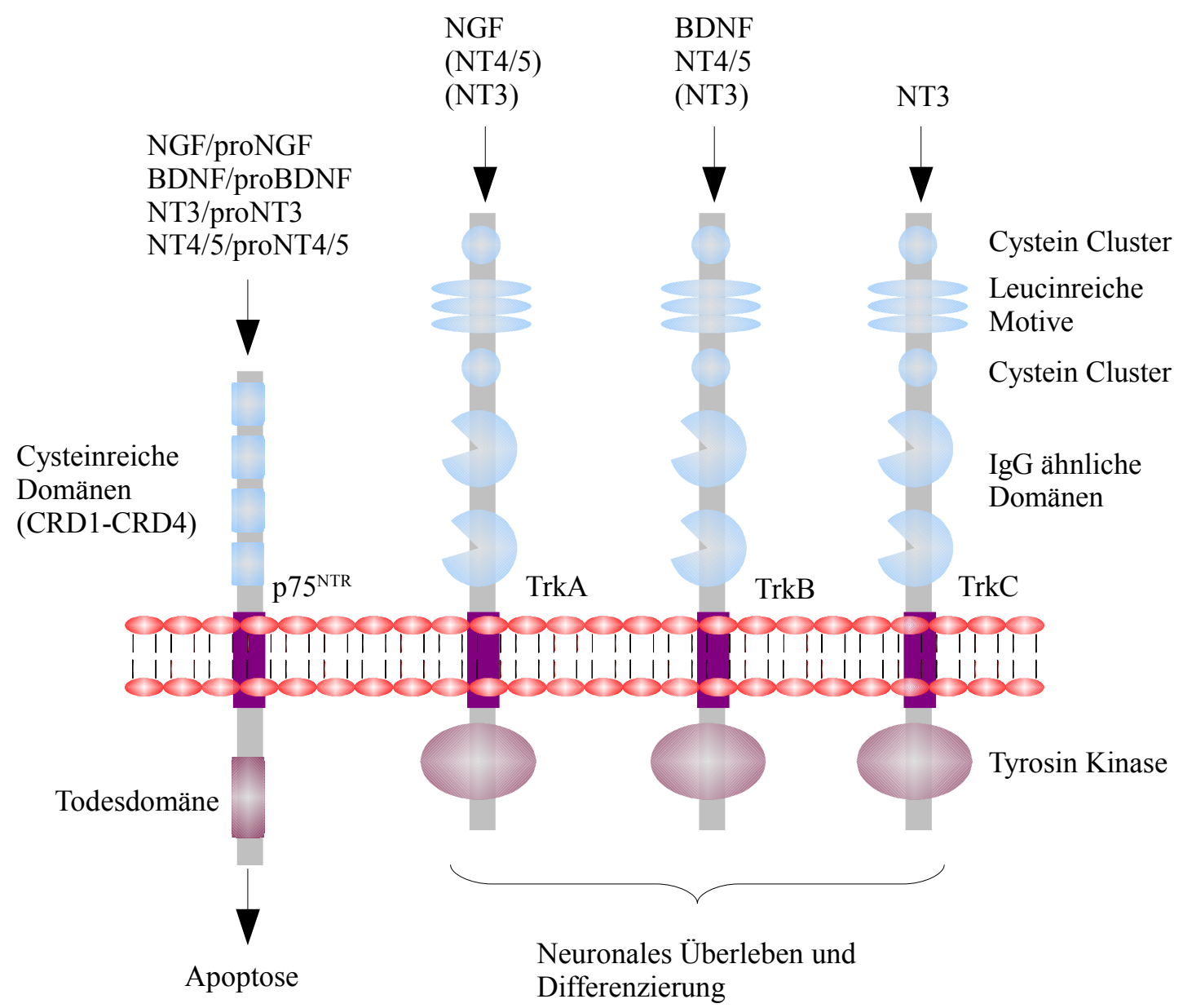

Abbildung 3: Neurotrophine und ihre Rezeptoren. NGF kann mit Hilfe seiner unterschiedlichen Rezeptoren Funktionen wie neuronales Überleben, Apoptose und Differenzierung vermitteln. (Abbildung modifiziert nach Lu et al., 2005 und Dechant und Barde, 1997).

Die Rezeptoren TrkA und p75 ${ }^{\mathrm{NTR}}$ sind häufig auf der Oberfläche derselben Zellen exprimiert und koordinieren und modulieren die Antwort der Zelle auf die Neurotrophine. Während die Trk-Rezeptoren positive Signale wie Überleben und Wachstum übermitteln (Huang und Reichardt, 2001; Patapoutian und Reichardt, 2001) kann p75 ${ }^{\text {NTR }}$ sowohl Überleben und Wachstum als auch die Apoptose vermitteln. Die Signale der beiden Rezeptorfamilien können sich entweder gegenseitig verstärken oder hemmen. Sie koexistieren somit in einer paradoxen Beziehung, in der jeder die Aktionen des Anderen entweder hemmt oder verstärkt. Die Wirkung von NGF wird 
durch ein feines Zusammenspiel beider Rezeptoren vermittelt. Beide Rezeptoren zeigen direkte Interaktionen durch Bildung eines Rezeptorkomplexes, der eine hoch wirksame Bindung von NGF ermöglicht (Hempstead et al., 1991; Benedetti et al., 1993). Neben der Verstärkung der Bindung von TrkA und NGF unterstützt p75 Autophosphorylierung von TrkA (Barker und Shooter, 1994) und fördert somit das TrkA-vermittelte neuronale Überleben. In Abwesenheit von TrkA führt die Expression von p75 ${ }^{\mathrm{NTR}}$ zur NGF-vermittelten Apoptose in neuronalen Zellen (Rabizadeh et al., 1993). Die Entscheidung zwischen Überleben und Tod der Zellen ist somit abhängig vom Verhältnis von p75 ${ }^{\text {NTR }}$ zu TrkA Rezeptoren (Yoon et al., 1998; Dechant und Barde, 1997).

\subsubsection{Der NGF-Signalweg}

Bindet NGF an einen passenden Rezeptor wird sofort eine Reihe von Signalkaskaden in Gang gesetzt. An dieser Stelle werden lediglich die wichtigsten TrkA-,,Downstream“Signalwege kurz beschrieben, da gezeigt werden konnte, dass die Induktion von Klf10 durch NGF über den TrkA-Signalweg erfolgt (Spittau et al., 2010) und dieser Signalweg somit den für die vorliegende Arbeit relevanten Signalweg darstellt. Nach der Bindung von NGF an den TrkA-Rezeptor kommt es zunächst zur Rezeptordimeri-sierung und Kinaseaktivierung (Patapoutian und Reichardt, 2001). Jeder Trk-Rezeptor verfügt über 10 konservierte Tyrosine in der zytoplasmatischen Domäne, von denen sich drei in der autoregulatorischen Schleife der Kinase-Domäne befinden. Die Phosphorylierung dieser Aminosäuren aktiviert die Kinase, während durch die Phosphorylierung der anderen Tyrosin-Reste „docking sites“ für die sog. Adaptermoleküle entstehen. Diese verbinden die Rezeptoren mit intrazellulären Signalkaskaden. Als wichtigste Signalkaskaden wären hier der „Ras/ㅌxtrecellular- signal regulated kinase“- (Ras/Erk-)Signalweg, der

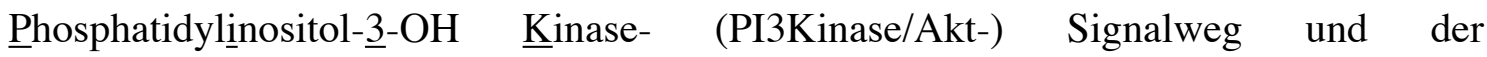
Phospholipase $\underline{\mathrm{C}}-\gamma 1$ - (PLC- $\gamma 1$-) Signalweg zu nennen (s. Abb. 5) (Chao, 2003; Miller und Kaplan, 2001). Das Src-homologe und C ollagen-ähnliche Adapter-Protein shc verbindet den TrkA-Rezeptor mit zwei voneinander getrennten Signalwegen. Der Ras/ Erk-Signalweg reguliert neuronales Wachstum durch die Aktivierung des „mitogenactivated protein kinases“ (MAPKs)/ERK-Signalweges.\#

Das Shc-Adaptermolekül bindet an den aktivierten TrkA-Rezeptor welcher Grb2 und „s- 


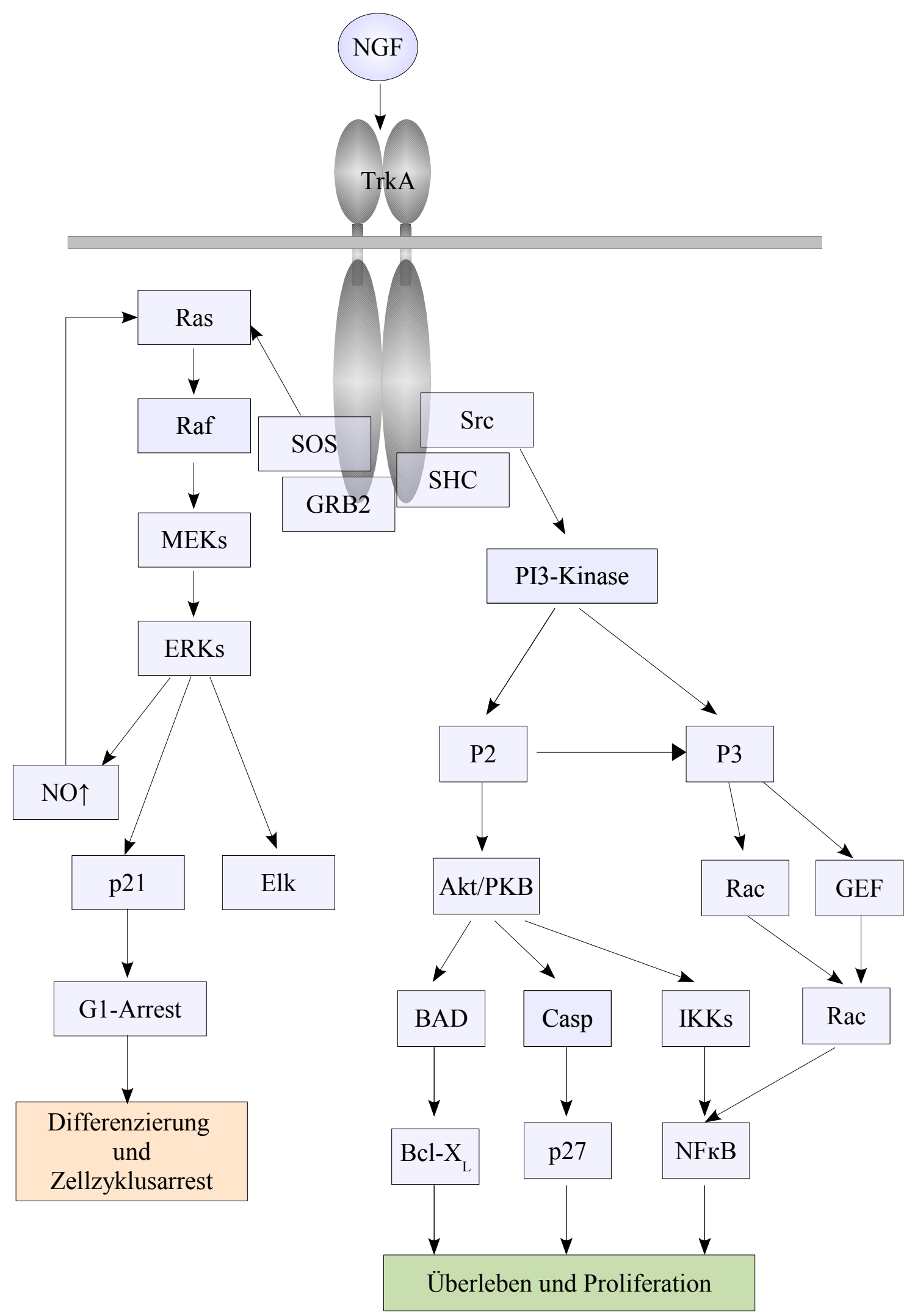

Abbildung 4: Der NGF-Signalweg (Abbildung modifiziert nach Chao, 2003 und Patapoutian und Reichardt 2001).

Ras und in Folge zur Aktivierung des „downstream“ Signalweges, der die c-Raf/B-Raf/ Erk1/Erk2 und p38MAPK mit einschließt (Chao, 2003). Neuronales Überleben wird 
durch die Shc vermittelte Aktivierung des PI3-Kinase/Akt Signalwegs vermittelt. Eine Induktion der PI3K kann zum Einen durch die drei Adapterproteine Shc, Grb2 und Gab1 erfolgen, aber auch eine Aktivierung der PI3K durch Raf ist möglich (Chao, 2003). Die PLC- $\gamma$ wird direkt zu einem Tyrosinrest am kurzen Schwanz des TrkARezeptors rekrutiert und katalysiert die Hydrolyse von Phosphatidylinosit, wodurch man Inositol-1,4,5-Triphosphat $\left(\mathrm{IP}_{3}\right)$ sowie Diacylglycerol erhöht. Letzteres aktiviert die Proteinkinase $\mathrm{C}(\mathrm{PKC}-\delta)$ welche wiederum die MEK/Erk-Aktivität reguliert (Patapoutian und Reichardt, 2001; Chao, 2003).

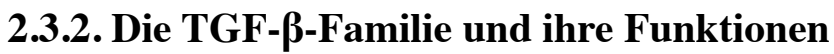

TGF- $\beta$ repräsentiert den Prototypen einer Familie von mehr als 30 strukturell verwandten jedoch funktionell unterschiedlichen Wachstumsfaktoren, die sowohl in Säugetieren, als auch in Insekten oder Würmern konserviert sind. Es sind drei TGF- $\beta$ Isoformen, vier Aktivin-Isoformen und die BMPs bekannt, wobei die BMPs mit mehr als 20 Isoformen die Größte Subpopulation unter den TGF- $\beta$-Familienmitgliedern darstellen (Massagué, 1998; Derynck und Feng, 1997). Die Mitglieder der TGF- $\beta$ Familie beeinflussen eine Reihe von zellulären Aktivitäten (Roberts und Sporn, 1989; Massagué, J., 1990). Ihr Gründungsmitglied TGF- $\beta$ wurde ursprünglich als ein Faktor identifiziert, der das Wachstum von Rattennierenfibroblasten auf Softagar induziert (Roberts et al., 1981). Aufgrund dieser Eigenschaft erhielt es den Namen „,Transforming growth factor-beta“ (TGF- $\beta$ ). Im Laufe der Zeit wurde jedoch klar, dass es sich um ein Protein mit multifunktionellen Eigenschaften handelt. Es hat Einfluss auf Funktionen wie Proliferation, Differenzierung, Apoptose, Adhäsion und Migration von verschiedenen Zelltypen und ist an der Bildung von extrazellulären Matrixproteinen beteiligt (Dennler et al., 2002). Die Deregulation der TGF- $\beta$-Signaltransduktion ist an einer Vielzahl von Erkrankungen, wie z.B. Autoimmunerkrankungen, der Entstehung von Tumoren, Fibrose und vaskulären Fehlfunktionen beteiligt (Wharton und Derynck, 2009).

\subsubsection{Die TGF- $\beta$-Rezeptoren}

In den vergangenen Jahrzehnten konnten viele unterschiedliche TypI- und TypIIRezeptoren identifiziert werden, wobei die TypI-Rezeptoren häufig auch als „Aktivin receptor like kinases“ (ALK) bezeichnet werden. TGF- $\beta$, BMP und Aktivin 
signalisieren jeweils durch unterschiedliche Rezeptoren (Derynck und Feng, 1997; Massagué, 1998) (s. Tabelle 4).

Tabelle 4: TypI- und TypII-Rezeptoren der TGF- $\beta$-Familie, Liganden und korrespondierende Smads (Tabelle modifiziert nach Derynck und Zhang, 2003)

\begin{tabular}{|c|c|c|c|}
\hline TypII-Rezeptor & $\begin{array}{l}\text { TypI- Rezeptor } \\
\text { (Synonym) }\end{array}$ & Ligand & R-Smad \\
\hline \multirow[t]{3}{*}{ T $\beta$ RII } & ALK-5 (T $\beta R I)$ & TGF- $\beta$ & Smad2, Smad3 \\
\hline & ALK-1 & & Smad1, Smad5 \\
\hline & ALK-2 (ActRI) & & \\
\hline ActRII, ActRIIB & ALK-4 (ActRIB) & Activin, Inhibin & Smad2 \\
\hline ActRIIB & ALK-7 & Nodal, GDF1, Vg1 & Smad2 \\
\hline \multirow[t]{3}{*}{ BMPRII } & ALK-2 (ActRI) & BMP7 & Smad1, Smad5, Smad8 \\
\hline & ALK-3 (BMP-RIA) & $\begin{array}{l}\text { BMP2, BMP4, BMP7, } \\
\text { GDF5 }\end{array}$ & \\
\hline & ALK-6 (BMP-RIB) & & \\
\hline \multirow[t]{3}{*}{ AMHR } & ALK-2 (ActRI) & MIS & Smad1, Smad5 \\
\hline & ALK-3 (BMP-RIA) & & \\
\hline & ALK-6(BMP-RIB) & & \\
\hline
\end{tabular}

Bei den meisten Zelltypen bindet TGF- $\beta$ zunächst an einen T $\beta$ RII, um danach den T $\beta$ RI (ALK5) zu rekrutieren. Der T $\beta$ RI (ALK1) ist ein Rezeptor, der ausschließlich in Endothelzellen exprimiert wird. Zusätzlich zu den TypI- und TypII-Rezeptoren kann TGF- $\beta$ auch noch an die Transmembran-proteine Betaglycan, auch T $\beta$ RIII genannt, oder Endoglin binden. Diese beiden Rezeptoren haben keine intrinsischen enzymatischen Aktivitäten, doch es konnte gezeigt werden, dass sie den TGF- $\beta$ Signalweg beeinflussen können. Für Betaglycan (TßRIII) konnte gezeigt werden, dass er die Bindung von TGF- $\beta$ an den TypII-Rezeptor fördern kann. Auf welche Weise Endoglin an der T $\beta$ R-Signalübermittlung beteiligt ist, ist bislang noch unklar (van Ginkel et al., 1999; Wrana et al., 1994).

\subsubsection{Der TGF- $\beta$-Signalweg}

Die Signalübertragung der Mitglieder der TGF- $\beta$-Familie erfolgt über einen heteromeren Komplex von zwei Typen von Transmembranrezeptoren, die als TypI- und TypII- Rezeptoren bezeichnet werden (Derynck und Feng, 1997; Massagué, 1998). Bei 
dem TypII-Rezeptor handelt es sich um eine konstitutiv aktive Kinase, während die TypI-Rezeptor-Kinase durch den TypII-Rezeptor aktiviert werden muss.

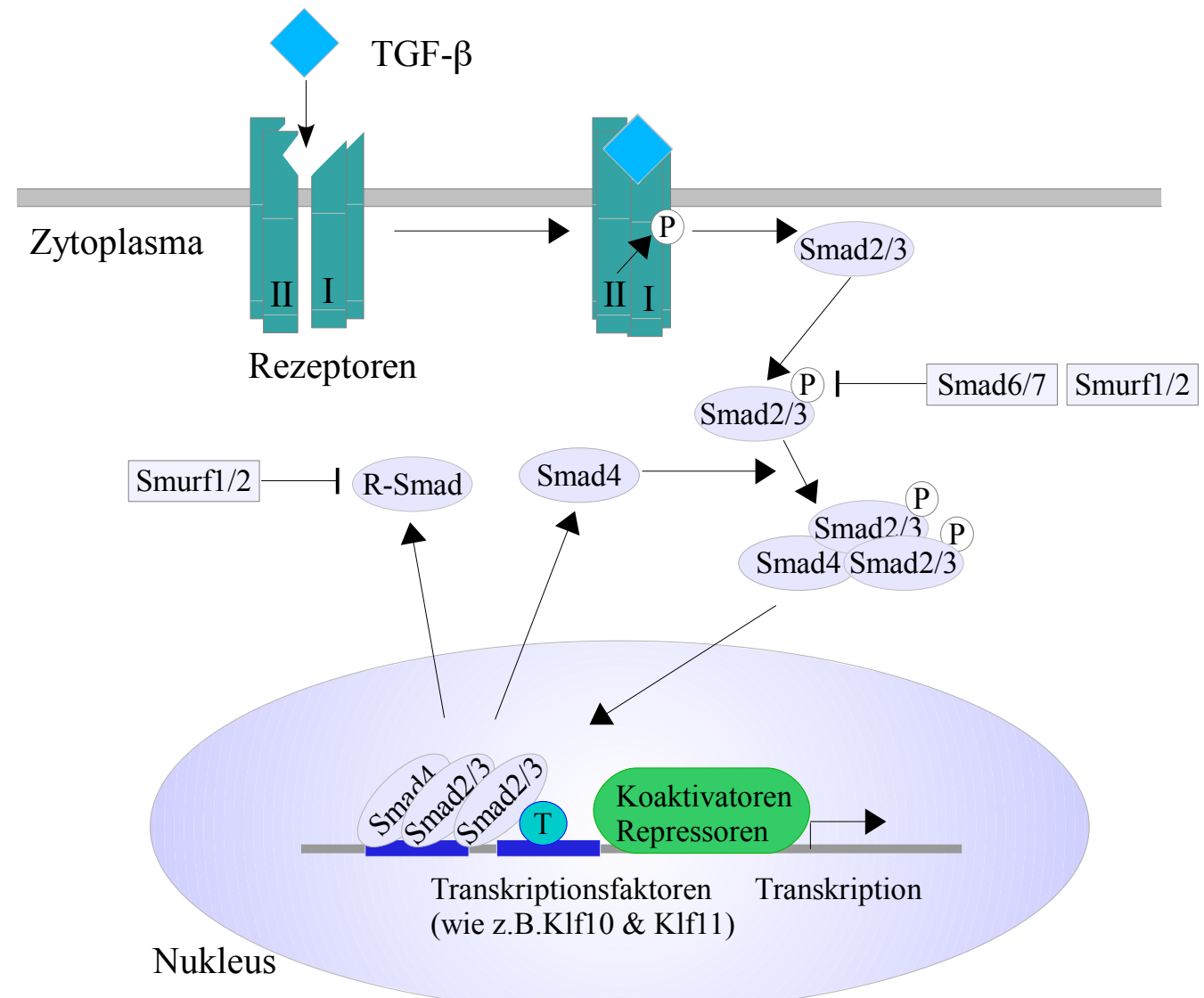

\begin{abstract}
Abbildung 5: Der Smad-abhängige TGF- $\beta$-Signalweg (Abbildung modifiziert nach Derynck und Zhang, 2003).
\end{abstract}

Beide verfügen über eine N-glycosylierte extrazelluläre Domäne, die reich an Cystinresten ist, eine Transmembrandomäne und eine intrazelluläre Serin/ThreoninKinase-Domäne. Nach der Bindung eines Liganden an den TypII-Rezeptor phosphoryliert dieser den TypI-Rezeptor an der GS-Domäne, die reich an Glycin und Serin/Threoninresten ist (Wrana et al., 1994). Dies führt zu einer Konformationsänderung des TypI-Rezeptors und die somit aktivierte Kinase phosphoryliert nun ihrerseits spezifische intrazelluläre Proteine (s. Abbildung 5).

\title{
2.3.2.3. Die Rolle der Smads im TGF-ß-Signalweg
}

TypI-Rezeptoren initiieren die intrazelluläre Signaltransduktion, indem sie spezifische Proteine, die Smads, phosphorylieren. Der Name Smad bildet sich aus Sma und Mad, den homologen Genen aus Drosophila melanogaster und Caenorhabditis elegans. Smad- 
Proteine lassen sich in drei verschiedene Klassen unterteilen: die rezeptorregulierten Smads (R-Smads), „common mediator“-Smads (Co-Smads) und die inhibitorischenSmads (I-Smads) (Abbildung 6). Alle Smad-Proteine teilen sich zwei hoch konservierte

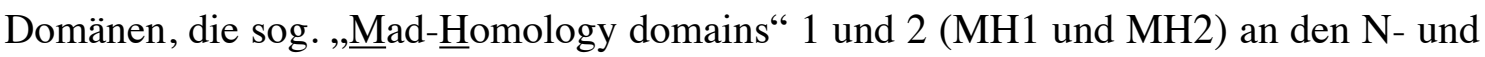
C-terminalen Enden der Proteine (s. Abbildung 6).

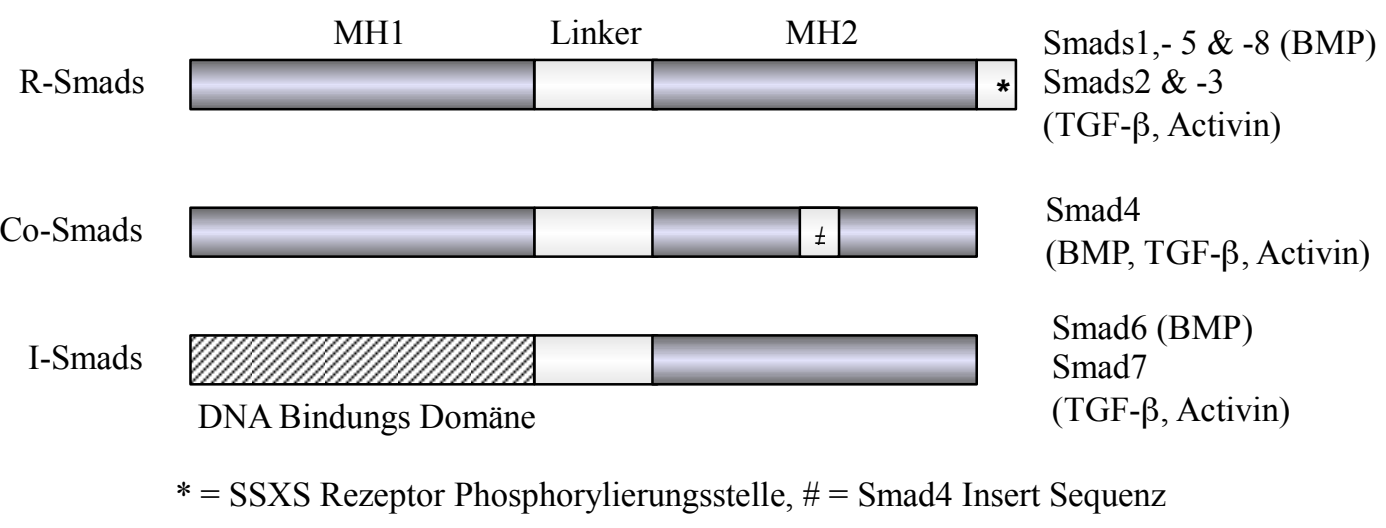

Abbildung 6: Übersicht über die Smad Proteine (Abbildung modifiziert nach Dennler et al., 2002).

Eine prolinreiche Region von variabler Länge schließt sich an diese zwei Domänen an. Zytosolische R-Smads interagieren mittels ihrer MH2-Domäne transient mit den aktivierten TypI-Rezeptoren und werden durch diese an ihren C-terminalen Serinresten phosphoryliert (Abdollah et al., 1997; Souchelnytski et al., 1997). Nach der Aktivierung bilden R-Smads und Co-Smads heterogene Komplexe und tanslozieren in den Zellkern, wo sie die Expression von Zielgenen beeinflussen. Inhibitorische Smads, die I-Smads verhindern die Signalübermittlung der R- und Co-Smads. Sie interagieren effizient mit dem aktivierten TypI-Rezeptor und konkurrieren mit den R-Smads um die Bindung anden Rezeptor (Nakao et al., 1997, Imamaura et al., 1997a, Schuster und Krieglstein, 2001) (s. Abbildung 5). Neben der Smad-abhängigen TGF- $\beta$-Signalübertragung kann die TGF- $\beta$-Signaltransduktion Smad-unabhängig erfolgen. Da einiges darauf hindeutet, dass Klf10 und Klf11 über den Smad-abhängigen TGF- $\beta$-Signalweg reguliert werden (Cook und Urrutia, 2000), wird auf eine detaillierte Darstellung des Smadunabhängigen Signalwegs verzichtet.

\subsection{Transkriptionsfaktoren}

Transkriptionsfaktoren sind, abhängig von ihren strukturellen Merkmalen, in verschiedene Klassen unterteilt. Eines dieser strukturellen Merkmale, das in der 
jüngeren Vergangenheit viel Aufmerksamkeit erregt hat ist das sogenannten Zinkfingermotiv, welches erstmals mit dem Xenopus-Transkriptionsfaktor TFIIIA (Miller et al., 1985) beschrieben wurde. Eine sehr gut charakterisierte Gruppe der Zinkfinger-Transkriptionsfaktoren ist die große Sp1-Familie und mit ihnen die Familie der Krüppel-ähnlichen Transkriptionsfaktoren.

\subsubsection{Die Familie der Sp1- und Krüppel-ähnlichen Transkriptionsfaktoren}

Sp1 (specificity protein 1), das Gründungsmitglied der Sp1- und Krüppel-ähnlichen Transkriptionsfaktoren, wurde 1983 von Dynan und Tijan entdeckt (Dynan und Tijan, 1983). Sie konnten zeigen, dass es mit Hilfe von drei $\mathrm{Cys}_{2} \mathrm{His}_{2}$-Zinkfingermotiven spezifisch an GC-reiche Sequenzen bindet. Eine ähnliche DNA-Bindungsdomäne fanden Kadonaga und Mitarbeiter in vielen Entwicklungsregulatoren in Drosophila vor; darunter auch den an der Embryonalentwicklung beteiligten Transkriptionsfaktor Krüppel (Kadonaga et al., 1987). In den folgenden Jahren wurden weitere Transkriptionsfaktoren mit Zinkfingermotiven, denen von Sp1 sehr ähnlich, identifiziert. Sie definierten zusammen eine neue Klasse: die Sp1- bzw. Krüppel-ähnlichen Transkriptionsfaktoren (Kaczynski et al., 2003), auch kurz Sp/XKLF-Familie genannt (s. Abbildung 7).

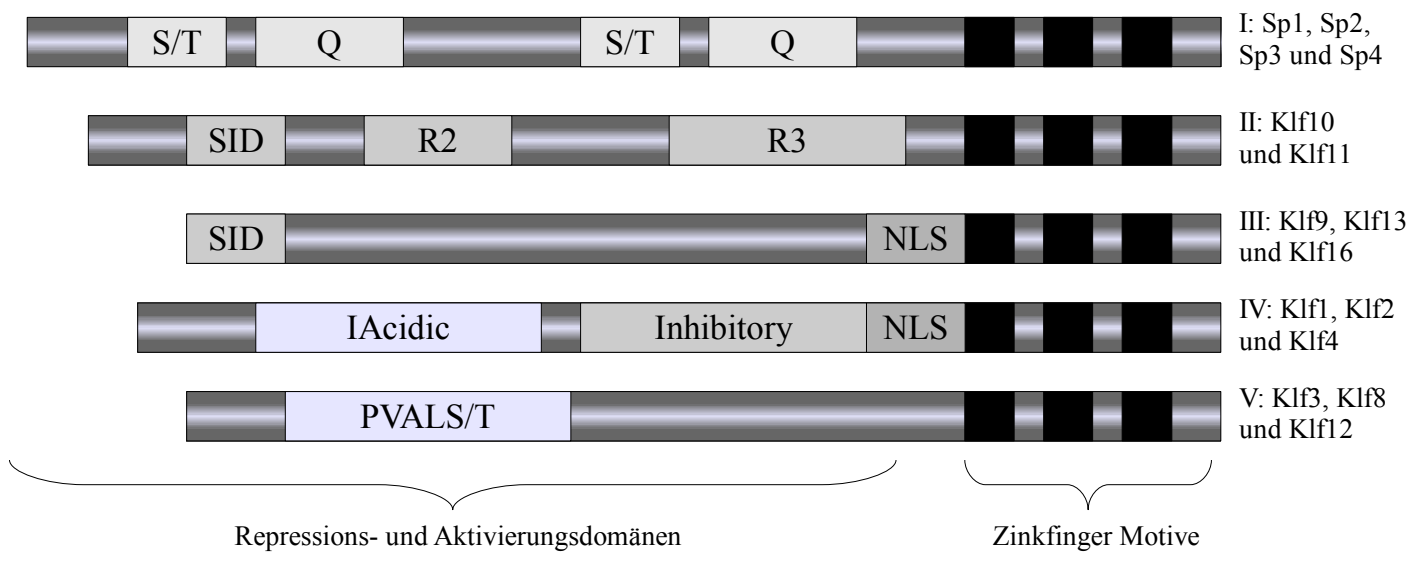

Abbildung 7: Strukturelle Eigenschaften der Sp1- und Krüppelähnlichen Transkriptionsfaktoren (Abbildung modifiziert nach Kaczynski et al., 2003).

Sp1/XKLF Proteine sind vom Fadenwurm Caenorhabditis elegans (C. elegans) bis hin zum Menschen vermutlich in allen Spezies vertreten. Im Menschen konnten bisher 23 Sp1/XKLF Gene identifiziert werden, davon acht Sp1-Faktoren und 15 Krüppelähnliche Faktoren (Bouwman und Philipsen, 2002). In der Maus wurden bis heute 17 Homologe der 23 Sp1/XKLF Gene nachgewiesen und in der Ratte 11 (Cook und 
Urrutia, 2000). Wie schon der Name Sp1/XKLF-Familie vermuten lässt, kann man diese in zwei Gruppen unterteilen. Die Gruppe der Sp1-Transkriptionsfaktoren weist nicht nur eine hohe Homologie in der Zinkfingerregion auf; auch ihre N-terminalen Regionen verfügen über homologe Motive. Die Krüppel-ähnlichen Transkriptionsfaktoren bilden dagegen eine zweite, vergleichsweise heterogene Gruppe (Phillipsen und Suske, 1999).

\subsubsection{Die Transkriptionsfaktoren Klf10 und Klf11}

KLF10 wurde erstmals 1995 von Subramaniam et al. als TGF- $\beta$-induzierbares Gen in fetalen humanen Osteoblasten beschrieben, dessen mRNA-Level innerhalb von 30 Minuten nach Behandlung mit TGF- $\beta 1$ anstieg und $2 \mathrm{~h}$ nach Behandlung ein Maximum erreichte. Mit KLF11 entdeckten Cook und Mitarbeiter drei Jahre später, 1998, ein neues Mitglied der Sp1-Familie (Cook et al., 1998). Weiterhin wurden Klf10 und Klf11 als murine Isoformen charakterisiert (Yajima et al., 1997; Wang et al., 2004). Die beinahe ubiquitär exprimierten Gene bildeten nun zusammen eine neue Untergruppe innerhalb der Krüppel-ähnlichen Zinkfingergene. In den folgenden Jahren wurde die Expression von Klf10 und Klf11, sowie deren Funktion in unterschiedlichen Geweben und Zelltypen in verschiedenen Spezies untersucht.

\subsubsection{Die strukturellen Eigenschaften von KIf10 und Klf11}

Um ein besseres Verständnis der Funktion von KLF10 und KLF11 zu erlangen, charakterisierten Tiffany Cook und ihre Mitarbeiter 1999 zunächst die strukturellen Eigenschaften dieser Proteine. Eine ihrer auffälligsten Besonderheiten sind drei $\mathrm{Cys}_{2} \mathrm{His}_{2}$-Zinkfinger-DNA-Bindungsmotive an ihrem C-terminalen Ende, die eine große

Homologie mit denen der Sp1-Transkriptionsfaktoren aufweisen. Das Gründungsmitglied der Familie der Sp1-Transkriptionsfaktoren, Sp1, verwendet dieses Motiv, um an GC-reiche (GGGGCGGGG) bzw. GT-reiche (GGTGTGGGG) Sequenzen zu binden (Bouwman und Philipsen, 2002). Diese sogenannten GC- und GT- Boxen sind wichtig für die Expression vieler zellulärer und viraler Gene und tragen zur Regulation einer großen Anzahl von wachstumsregulierenden Genen bei. Strukturelle Analysen lassen die Vor-hersage zu, dass sowohl Klf10 als auch Klf11 in der Lage sind, in Beziehung zu Sp1 stehende GC-reiche Sequenzen zu erkennen. Obwohl viele Mitglieder der Sp1-Familie transkriptionelle Aktivatoren sind, können sowohl Klf10 als 
auch Klf11 als starke transkriptionelle Repressoren wirken (Cook und Urrutia, 2000). Diese Fähigkeit ist in drei stark konservierten Repressormotiven, auch Repressionsdomänen genannt, begründet. Diese sind N-terminal vom Zinkfingermotiv lokalisiert. Für die humanen Isoformen KLF10 und KLF11 konnte gezeigt werden, dass innerhalb der ersten Repressionsdomäne ein alphahelikales Motiv lokalisiert ist, das mit dem Co-Repressor mSin3A interagiert. Diese wird als „mSin3A interacting domain“ (SID) bezeichnet (Zhang et al., 2001). Die Repressormotive von Klf10 und Klf11 werden durch vier „Linker“-Regionen (Verbindungs-Regionen) voneinander und von der DNA-Bindungsdomäne getrennt. Innerhalb dieser „Linker“-Regionen sind mehrere Stellen für posttranslationale Modifiationen enthalten (Cook und Urrutia, 2000). Die Rolle dieser „Linker“-Regionen ist bisher jedoch noch weitgehend ungeklärt. Weiterhin enthält KLF11 ein Tetrapeptid innerhalb der Zinkfingerregion, das als Kernlokalisationssignal dient (Nuclear localization site, NLS) (Gebelein et al., 1998). Ein ähnliches Signal wurde ebenfalls bei der murinen Isoform Klf11 entdeckt (Spittau et al., 2007). Für das humane KLF11 konnte gezeigt werden, dass eine Phosphorylierung durch die ERK/MAPK in Pankreaskarzinomzellen zu einem Verlust der Repressionsaktivität führt (Ellenrieder et al. 2004). Jüngere Untersuchungen haben gezeigt, dass Klf10 und Klf11 auch in verschiedenen Zelltypen als transkriptionelle Aktivatoren wirken können (Noti et al., 2004; Neve et al., 2005). Erst kürzlich wurde der Mechanismus für die durch Klf11 vermittelte transkriptionelle Aktivierung des „pancreatic-duodenal- homeobox-1“-Gens Pdx1 aufgeklärt. Dabei bindet Klf11 an eine Konsensussequenz innerhalb des Pdx1-Promotors und bildet mit dem Co-Aktivator p300 einen Komplex, welcher die Expression von Pdx-1 antreibt (Fernandez-Zapico et al., 2009). Die Autoren konnten in ihrer Studie beweisen, dass p300 dabei an das Cterminale Ende von Klf11 bindet, welches die drei Zinkfingermotive beinhaltet. Diese Ergebnisse decken sich mit den Resultaten von Spittau und Mitarbeitern, die herausfanden, dass das C-terminale Ende von Klf11 die Expression des LuciferaseReportergens steigern kann (Spittau et al., 2007). Mit Hilfe eines Gal4-Tieg1/Klf10Fusionskonstrukts konnte nachgewiesen werden, dass die Behandlung von PC12-Zellen mit NGF die Klf10-vermittelte transkriptionelle Repression verstärkt. Dieses Ergebnis deutet ebenfalls darauf hin, dass durch die Aktivierung des NGF-Signalweges eine posttranslationale Modifikation statt-finden könnte, die das inhibitorische Potential von Klf10 verstärkt (Spittau et al., 2010). 


\subsubsection{Die Expression von Klf10 und Klf11}

Klf10 und Klf11 zeigen ein nahezu ubiquitäres Expressionsmuster. Eine Übersicht über die Expressionsorte von Klf10 und Klf11 und deren Funktionen liefert Tabelle 4.

Tabelle 5: Expressionsorte und Funktionen von KIf10 und Klf11 in Organen und Geweben

\begin{tabular}{llll}
\hline & Expressionsort & Funktion & Quelle \\
\hline KLF10 & $\begin{array}{l}\text { fetale humane Osteoblasten, skelettales } \\
\text { Muskelgewebe }\end{array}$ & nicht beschrieben & $\begin{array}{l}\text { Subramaniam } \\
\text { et al. 1995 }\end{array}$ \\
\hline & $\begin{array}{l}\text { acinare und ductulare Epithelzellen des } \\
\text { exokrinen Pankreas, }\end{array}$ & Apoptose & $\begin{array}{l}\text { Tachibana } \\
\text { et al., 1997 }\end{array}$ \\
\hline Klf10 & $\begin{array}{l}\text { Niere, Lunge, Gehirn, Leber, Herz und Testis, } \\
\text { im adulten Ge-hirn im Hippokampus, } \\
\text { zerebralen Kortex, Cerebellum, Amyg-dala, } \\
\text { geringere Level in Striatum, Nucleus }\end{array}$ & Transkription $\downarrow$ & Yajima et al., 1997 \\
& $\begin{array}{l}\text { accumbens, olfak-torischem Tubercle, } \\
\text { Thalamus und der Substantia nigra }\end{array}$ & & \\
\hline Klf10 & $\begin{array}{l}\text { Testis, Niere, Skelettmuskel, Leber, Lunge, } \\
\text { Milz, Hirn und Herz }\end{array}$ & nicht beschrieben & Fautsch et al., \\
& ubiquitär & Transktiption $\downarrow$, S1- & Cook et al., 1998 \\
\hline KLF11 & & arrest & \\
\hline
\end{tabular}

\subsubsection{Die Induktion von Klf10 und Klf11}

Sehr bald wurde erkannt, dass sich Klf10 und Klf11 nicht nur durch TGF- $\beta$, sondern auch durch andere Mitglieder der TGF- $\beta$-Familie induzieren lassen. Eine Induktion von Klf10 wurde z.B. nach Behandlung unterschiedlicher Zelltypen mit BMP2, BMP4 (Alvares-Rodríguez et al., 2007; Hefferan et al., 2000a), AktivinA (Hefferan et al., 2000b) und GDNF (Yajima et al., 1997) als Mitglieder der TGF- $\beta$-Familie beschrieben. Außerdem wurde gezeigt, dass Östrogen (Tau et al., 1998), zytostatische Wirkstoffe, wie Homoharringtonine und Velcade (Jin et al., 2007) sowie Stickoxide (Mitsumoto et al., 2003) die Transkription von Klf10 steigern können. Kürzlich berichteten Wahab und Mitarbeiter (2005) eine TrkA-abhängige Steigerung der Expression von Klf10 nach der Behandlung von Mesangiumzellen mit CTGF. Dieses Resultat, zusammen mit Studien, die eine BDNF-vermittelte Induktion von Klf10 gezeigt haben (Wibrand et al., 2006), gaben Anlass zu der Vermutung, dass Klf10 ebenfalls ein Zielgen des NervenWachstumsfaktors NGF sein könnte. Untersuchungen an der Phäochromocytomzelllinie PC12, welche häufig als Modell für Untersuchungen des NGF-Signalweges dient, bestätigten dies (Spittau et al., 2010). Im Unterschied zur Regulation durch TGF- $\beta$ oder 
Mitgliedern der TGF- $\beta$-Familie, bei der meist zugleich Klf10 und Klf11 induziert werden, sind Klf10 und Klf11 durch NGF gegenläufig reguliert, das heißt, Klf10 wird hochreguliert während Klf11 herrunterreguliert wird. Die Hochregulation von Klf10 wurde dabei zumindest für Klf10 auf transkriptioneller sowie auf translationeller Ebene gezeigt (Spittau et al., 2010).

\subsubsection{Die antiproliferative Wirkung von Klf10 und Klf11}

Cook und und ihre Mitarbeiter fanden 1999 mit Hilfe von GAL4-abhängigen Luciferase-Assays heraus, dass KLF10 und KLF11 drei konservierte transkriptionshemmende Domänen aufweisen (Cook et al., 1999). Aufgrund dieser strukturellen Besonderheit bilden sie eine neue Unterfamilie innerhalb der Sp1-ähnlichen Zinkfingerproteine. Bereits diese molekularen und biochemischen Charakteristika von Klf10 und Klf11 deuten stark auf eine Rolle bei der Zellzykluskontrolle hin (Cook und Urrutia, 2000). Aufgrund ihrer Fähigkeit, ähnlich wie Sp1, an GC-reiche Sequenzen zu binden, sind sie potentiell in der Lage die Transkription einer Vielzahl von zellzyklusregulierenden Genen wie z.B. p15, p21 (Moustakas und Kardassis, 1998; Prowse et al., 1997) und p27 (Zhang und Lin, 1997), MAP-Kinasen, mitogene GTPasen (H-ras) (Ishii et al., 1986), DNA-Synthese-Proteine (Birnbaum et al., 1995), Wachstumsfaktoren (z.B. TGF- $\beta$, „Fibroblast growth factor“ FGF u.a.) (Geiser et al., 1993) und Wachstumsfaktor-Rezeptoren (,insulin receptor“ und, insulin-like growth factor receptor") (Beitner-Johnsen et al., 1995) zu beeinflussen. Es konnte bereits mehrfach gezeigt werden, dass Klf10 in der Lage ist in verschiedenen Zelltypen die Proliferation zu hemmen (Tachibana et al., 1997; Tau et al., 1998; Hefferan et al., 2000b; AlvarezRodríguez et al., 2007 und Spittau et al., 2010). Ähnliche Ergebnisse sind für Klf11 bekannt (Cook et al., 1998; Buck et al., 2006). Dabei können die Mechanismen, durch die Klf10 und Klf11 die Proliferation beeinflussen, bisher nur teilweise erklärt werden. Bei der BMP2-vermittelten Differenzierung von Vorläufern der Körnerzellen des Kleinhirns, den CGNPs (,cerebellar granular neuronal precursers“) kommt es zu zwei wesentlichen Ereignissen: die Zellen stellen ihr Wachstum ein und beginnen sich zu differenzieren. Alvarez-Rodríguez und Mitarbeiter fanden 2007 heraus, dass Klf10 zwar für den Zellzyklusarrest der CGNPs notwendig ist, nicht jedoch für die Differenzierung dieser Zellen (Alvarez-Rodríguez et al., 2007). Ein ähnliches Ergebnis lieferte kürzlich eine, an der Phäochromozytomzellinie PC12 durchgeführte, Studie. Bei der Induktion 
der Differenzierung dieser Zellen mit NGF wurde Klf10 unmittelbar durch NGF induziert. Bei Überexpression von Klf10 zeigte sich, dass der Transkriptionsfaktor in der Lage ist, die Proliferation abzuschwächen, jedoch alleine nicht zur Differenzierung der Zellen führt (Spittau et al., 2010). Für Klf11 ist bekannt, dass es auf eine TGF- $\beta$ abhängige Weise mit Smad3 interagiert und dadurch die Expression von c-myc hemmt. Diese Interaktion wird durch die Präsenz eines aktiven ERK-Signalweges unterbrochen, was auf einen möglichen Mechanismus für die Hemmung des TGF- $\beta$-vermittelten Wachstumsarrestes hindeutet (Buck et al., 2006).

\subsubsection{Die proapoptotische Wirkung von Klf10 und Klf11}

In der TGF- $\beta 1$-sensitiven Leberzelllinie Hep3B führt die Überexpression von KLF10, ähnlich wie bei der TGF- $\beta$ vermittelten Apoptose, zur Bildung von freien Radikalen, was eine Veränderung des Membranpotentials der Mitochondrien und infolgedessen die, für apoptotische Zellen typischen, morphologischen Veränderungen zur Folge hat (Ribeiro et al., 1999). Ektopische Überexpression von Klf10 in der epithelialen Mv1LuZelllinie (Zellen aus der Lunge eines Nerz) führt, ebenso wie die Behandlung mit TGF$\beta$, zu einem reduzierten Bcl-2-Proteinlevel. Bcl-2 kann sowohl vor dem Caspase abhängigen Zelltod schützen, indem es die Aktivierung der sog. „Henkercaspasen“ hemmt, als auch vor dem caspaseunabhängigen Zelltod, indem es das Membranpotential der Mitoch-ondrien stabilisiert. Eine Reduktion des Bcl-2-Proteinlevels durch TGF- $\beta$ oder KLF10 fördert somit die Apoptose in dieser Zelllinie (Chalaux et al., 1999). Auch in der oligodendroglialen Zelllinie Oli-neu kam es zu einer Verstärkung der TGF$\beta$-vermittelten Apoptose durch Klf10. Ektopische Überexpression von Klf10 in Oli-neu Zellen führt zu vermehrtem Zelltod. Anders als in Mv1Lu-Epithelzellen werden in dieser Zelllinie die Bcl2-Proteinlevel jedoch nicht durch Klf10 beeinflusst. Dagegen ist hier ein anderes antiapoptotisches Mitglied der Bcl2-Familie, Bcl- $\mathrm{X}_{\mathrm{L}}$ auf transkriptioneller wie translationeller Ebene herrunterreguliert. Ähnlich wie in Mc1Lu-Zellen ist in dieser Zelllinie ebenfalls die Smad7-Promotoraktivität im Luciferase-Assay verringert, wobei jedoch die Aktivität der R-Smads gesteigert wird (Bender et al., 2004). Weiterhin wurde bei Microarray-Analysen nach der Behandlung von HL60-Zellen mit dem zytotoxischen Alkaloid Homoharringtonin eine starke Induktion der Klf10 mRNA beobachtet, was ebenfalls auf eine Mitwirkung von Klf10 bei der Apoptose hindeutet (Jin et al., 2007). Überexpressionsstudien mit KLF11 von Cook und Mitarbeitern 
deuteten bereits 1998 darauf hin, dass auch KLF11 epitheliales Zellwachstum von CHO-Zellen inhibieren kann (Cook et al., 1998). Weiterhin ist Klf11 in der Lage den TGF- $\beta$-Signalweg durch Herunterregulation des inhibitorischen Smad7 zu potenzieren. Dies erfolgt durch Blockierung der TGF- $\beta$-vermittelten Induktion des Smad7Promotors mit Hilfe des Corepressors mSin3a. Diese Funktion kann jedoch durch Phosphorylierung von Klf11 an den vier sog. „Erk consensus sites“ ( $\mathrm{T}_{56}, \mathrm{~S}_{94}, \mathrm{~S}_{107}$ und $\mathrm{S}_{149}$ ) durch den ERK-MAPK-Signalweg (s. o.) inaktiviert werden (Ellenrieder et al., 2004). Auch in Oli-neu-Zellen führt die Überexpression von Klf11 zu einer Aktivierung der Caspase-3 und infolgedessen zu einer gesteigerten Apoptoserate. Im Gegensatz zu früheren Arbeiten mit dieser Zelllinie, bei denen die Überexpression von Klf10 zu einer verringerten Aktivität des „Survival“-Faktors NF- $\varkappa$ B geführt hat, ist die Aktivität dieses Faktors jedoch nach Überexpression von Klf11 erhöht. Wie auch schon für Klf10 beschrieben war die Aktivität der R-Smads erhöht. Dagegen waren die Smad7Promotoraktivität sowie die Smad7-Proteinexpression nach Klf11-Überexpression verringert. Dabei wurden sowohl für die Verringerung der Promotoraktivität, als auch für die Verringerung der Proteinexpression von Smad7, die N-terminalen Repressionsdomänen von Klf11 benötigt. Bei Transfektion der Zellen mit trunkiertem Klf11, zeigten sich diese Effekte nicht (Gohla et al., 2008b).

\subsubsection{Die Klf10- und Klf11- Knockout-Mäuse}

Bei oberflächlicher Betrachtung zeigen Klf10-“Knockout"-Mäuse zunächst einen unauffälligen Phänotyp und „normale“ Zuchtcharakteristika. Bei histomorphometrischer Untersuchung der Tibiae stellte sich jedoch heraus, dass die Anzahl der Osteoblasten der Spongiosa bei den Wildtypmäusen signifikant höher war als bei den Mutanten. Die Parameter der Knochenbildung waren jedoch nicht erhöht und bei der Anzahl der Osteoklasten gab es ebenfalls keine Unterschiede. Weiterhin zeigten die Klf10-/-Osteoblasten eine veränderte Expression wichtiger Osteoblasten-Markergene. Insgesamt zeigen die Ergebnisse, dass die Klf10-Expression in Osteoblasten sowohl an der Osteoblasten-vermittelten Mineralisierung als auch an dem Osteoblasten-Support der Osteoklasten-Differenzierung beteiligt ist (Subramaniam et al., 2005). Bei weiteren Studien zeigten weibliche „Knockout“-Mäuse im Vergleich zu Wildtyp-Mäusen einen osteoporotischen Phänotyp, mit signifikant schwächeren Knochen und reduzierten Anteilen von kortikalen und trabekulären Knochen. Insgesamt wird eine wichtige Rolle 
für die Skelettentwicklung und Erhaltung angenommen. (Bensamoun et al., 2006b). Rajamannan und Mitarbeiter fanden außerdem 2007 den Beweis, dass adulte männliche Klf10-/-Mutanten eine Herzhypertrophie entwickeln (Rajamannan et al., 2007). Im Herzgewebe der „Knockout“-Mäuse waren außerdem erhöhte ,pituitary tumortransforming gene-1“ (Pttg1) und Histon H3-Protein-Level nachzuweisen. Dies wirft die Vermutung auf, dass es sich bei Klf10 um einen negativen Regulator der Pttg1Protein Expression handelt. Die Arbeitsgruppe konnte außerdem eine erhöhte Histon H3- Expression in den Kardiomyozyten der männlichen Klf10-Mutanten nachweisen. Dieser Befund traf jedoch nur auf die untersuchten männlichen Tiere, nicht aber auf die weiblichen Tiere zu.

Der zirkadiane Rhythmus kontrolliert bei den Säugetieren eine Reihe physiologischer Aspekte und Verhaltensweisen, synchron mit dem externen Tag-Nacht-Rythmus. Dieser Rhythmus wird angetrieben durch selbsterhaltende endogene „Uhren“ die in nahezu allen Zellen des Körpers „ticken“. Das zirkadiane System wird hierarchisch durch eine „Hauptuhr“, die im suprachiasmatischen Nukleus lokalisiert ist und die auch in Abwesenheit äußerer Reize annähernd im 24 Stunden-Takt ossziliert, organisiert. Guillaumond und Mitarbeiter konnten feststellen, dass Klf10 ein robustes zirkadianes Expressionsmuster zeigt (Guillaumond et al., 2010). Bei der Untersuchung des LeberTranskriptoms der Klf10-Mutanten konnten sie 158 regulierte Gene nach-weisen, von denen einige an Ereignissen im Fett- und Kohlenhydratstoffwechsel beteiligt sind. Von diesen Stoffwechselgenen werden $56 \%$ zeitabhängig reguliert. Männliche Klf10 ${ }^{--}$ Mäuse zeigten eine Hyperglykämie, vergesellschaftet mit einer signifikanten, zeitabhängigen Hochregulierung des Glukoneogenesegens Pepck und einer gesteigerten Glukoseproduktion der Leber. Übereinstimmende, funktionelle Daten zeigten, dass der proximale „phosphoenyl-pyruvate-çarboxykinase-Promotor“ (Pepck-Promotor) direkt durch Klf10 gehemmt wird. Weibliche Klf10-/--Mäuse zeigen keine Hyperglykämie, haben jedoch höhere Plasmatriglyceridwerte. Mit diesen Ergebnissen übereinstimmend war die rhythmische Expression des Srebplc Gens, der ,fatty acid synthase“ Fas und Elovl6-Gen (,elengation of very long-chain fatty acid-like $\underline{6}$-gene“"), die dem lipogenen Signalweg angehören verändert. Insgesamt sprechen diese Daten dafür, dass es sich bei Klf10 um einen transkriptionellen Regulator handelt, der die „,molekulare Uhr“ mit dem Energiestoffwechsel der Leber verbindet (Guillaumond et al., 2010). 
Der Phänotyp der Klf11-“Knockout"-Mäuse lässt sich schnell zusammenfassen: es wurden keine Defizite gefunden. Klf11/--Mäuse sind vital, normal groß, fertil und folgen bei der Zucht der normalen Mendel'schen Genetik. Sie leben genauso lange wie Klf11+/+-Mäuse und hämatologische Untersuchungen zeigen ebenfalls keine Unterschiede (Song et al., 2005).

\subsection{Die Auswahl der Zelllinien Oli-neu und PC12}

Bei der Zelllinie Oli-neu handelt es sich um immortalisierte, oligodendrogliale Vorläuferzellen, die mit der neu-Kinase transformiert wurden. Sie bilden adhärente Monolayer und können sich sowohl zu Oligodendrozyten als auch zu Astrozyten differenzieren (Jung et al., 1998). Bei den Oli-neu-Zellen handelt es sich um ein, für die Erforschung der TGF- $\beta$-vermittelten Apoptose, etabliertes Zellmodell.

Die von Phäochromozytomzellen der Ratte hergeleiteten PC12-Zellen sind ein optimales Zellmodell für die Untersuchung der Neurotrophin-Signaltransduktion. NGFinduziert bei diesen Zellen, in serumhaltigem Wachstumsmedium, die Differenzierung zu einem Zelltyp, der sympathischen Neuronen ähnelt. Die Behandlung mit diesem Wachstumsfaktor führt zu einem Zellzyklusarrest, zur Ausbildung von Neuriten, zur Expression neuronaler Marker und zu elektrischer Erregbarkeit (Tischler and Greene, 1975; Greene and Tischler, 1976). Unter serumfreien Bedingungen und unter Abwesenheit von NGF begehen die Zellen programmierten Zelltod (Greene, 1978). Somit liefern die PC12-Zellen ein optimales Werkzeug für die Untersuchung der intrazellulären Signalwege, die an der Neurotrophin-Signaltransduktion beteiligt sind. Die Oli-neu-Zellen bilden zusammen mit den PC12-Zellen, Zellmodelle für die wichtigsten Zelltypen, die wesentliche Bestandteile des zentralen Nervensystems darstellen.

\subsection{Darstellung des Forschungsprojektes und Zielsetzung der vorliegenden Arbeit}

Während der Entwickung des Nervensystems findet zunächst eine Überproduktion der Vorläuferzellen statt, gefolgt von der Selektion der Zellen, die sich differenziert haben und angemessene Verbindungen knüpfen konnten, und der Elimination der überschüssigen Zellen. Dieser Prozess findet während zwei Phasen statt: Während der ersten Phase kommt es in der ventrikularen und subventrikularen Zone des sich entwickelnden Nervensystems zur Bildung von neuronalen Stamm- und Vorläuferzellen, die sich zu 
Neuronen und Gliazellen differenzieren, welche dann nach einem Migrationsprozess Gehirn und Rückenmark besiedeln. Die folgende Periode der Apoptose erfüllt zwei Funktionen: die undifferenzierten Progenitorzellen werden eliminiert und es wird sichergestellt, dass eine angemessene Zellzahl in den schnellwachsenden Geweben wie z.B. im zerebralen Kortex erhalten bleibt. Die zweite Phase der Apoptose findet im Nervensystem statt, sobald die frisch entwickelten Neuronen ihren Bestimmungsort erreicht haben und versuchen, synaptische Kontakte zu etablieren. Diese Periode des natürlichen neuronalen Zelltods eliminiert nahezu die Hälfte der vorher gebildeten Neurone (Miller et al., 2000; Oppenheim, 1991). Auch im ausgereiften Hirn reagieren die Zellen des Nervensystems auf zahlreiche Faktoren, die ihr Überleben und ihre Funktion beeinflussen. Wachstumsfaktoren, wie TGF- $\beta$ oder NGF stellen durch Regulation von Apoptose bzw. Überleben, Differenzierung und Zellzykluskontrolle wichtige Faktoren während dieser Phase der Entwicklung des zentralen Nervensystems dar. Es kristallisiert sich mehr und mehr heraus, dass sowohl Klf10 als auch Klf11 als Transkriptionsfaktoren wichtige Vermittler innerhalb des TGF- $\beta$-Signalweges sind und die Expression von TGF- $\beta$-Zielgenen regulieren. Die kürzlich von Wahab und Mitarbeitern (Wahab et al., 2005) entdeckte TrkA-abhängige Steigerung der Expression von Klf10 nach der Behandlung von Mesangiumzellen mit CTGF, und die Studien, die eine BDNF-vermittelte Induktion von Klf10 gezeigt haben (Wibrand et al., 2006), gaben Anlass zu der Vermutung, dass beide Transkriptionsfaktoren ebenfalls eine Rolle im NGF-Signalweg spielen könnten. Die vorliegende Arbeit beschäftigt sich mit den zellbiologischen Effekten, die sich nach Überexpression von Klf11 in Oli-neu-Zellen beobachten lassen. Bei Oli-neu-Zellen handelt es sich um immortalisierte Vorläuferzellen, die sich sowohl zu Oligodendrozyten als auch zu Astrozyten differenzieren lassen. Weiterhin wurden die TGF- $\beta$-unabhängigen Regulationen von Klf10 und Klf11 durch NGF in der Phächromozytomzelllinie PC12, sowie ihre Funktionen in diesem Zusammenhang untersucht. Beide Zelllinien zusammen können als Zellmodelle für drei wichtige Zelltypen dienen, die wesentliche Bestandteile des zentralen Nervensystems darstellen: den Gliazellen, den Astrozyten und den Neuronen. Zielsetzung dieser Arbeit war es, die Rolle der Sp1/Klf-ähnlichen Transkriptionsfaktoren Klf10 und Klf11 in diesem Kontext näher zu charakterisieren. Dabei wurden die folgenden Fragestellungen untersucht: 
1. Welche zellbiologischen Effekte lassen sich nach Überexpression von Klf11 in Oli-neu-Zellen beobachten?

2. Welche Rolle spielt Klf11 bei der TGF- $\beta$-vermittelten Apoptose in der Zelllinie Oli-neu?

3. Werden Klf10 und Klf11 in PC12-Zellen exprimiert und kommt es nach der Behandlung mit dem Nervenwachstumsfaktor NGF zu einer Induktion dieser Transkriptionsfaktoren?

4. Welche Rolle spielt Klf10 bei der NGF-vermittelten Differenzierung der PC12Zellen, die als Zellkultursystem stellvertretend für sympathische Neurone stehen und somit einen wesentlichen Bestandteil des zentralen Nervensystems darstellen?

\subsection{Diskussion und Ausblick}

\subsubsection{Die Rolle von KIf11 bei der TGF- $\beta$-vermittelten Apoptose}

„TGF- $\beta$-signaling“tablierten, TGF- $\beta$-responsiven Zelllinie Oli-neu, konnte die Rolle von Klf11 im TGF- $\beta$-Signalweg analysiert werden. Dabei wurde gezeigt, dass Klf11 die Aktionen von TGF- $\beta$, das heißt die Induktion der Apoptose durch die Aktivierung der Caspase3, imitiert. Weiterhin verstärkt Klf11 den TGF- $\beta \beta 1$ und verhindert so die Verstärkung der Smad-vermittelten TGF- $\beta$-Antworten (Gohla et al., 2008b). Klf11 teilt die meisten strukturellen und funktionellen Eigenschaften von Klf10 (Wang et al., 2004; Spittau et al., 2007). Es wurde bewiesen, dass sowohl TGF- $\beta$ als auch Klf10 in der Lage sind die Caspase 3 abhängige Apoptose in Oli-neu Zellen zu induzieren (Schuster et al., 2002; Bender $\beta$ in ähnlicher Weise imitiert wie Klf10 und ebenfalls als „Downstream“Vermittler der TGF- $\beta$, wie Klf10. Aufgrund der großen Ähnlichkeit zwischen Klf10 und Klf11, sowohl bei der Struktur als auch bei den Funktionen, wäre es interessant zu untersuchen, ob es ggf. kompensatorische Effekte zwischen beiden Proteinen gibt, auf die sich auch der „fehlende Phänotyp“ der Klf11-/-Mäusse (Song et al., 2005) und der relativ „milde Phenotyp“ der Klf10-/-Mäuse (Subramaniam et al., 2005; Bensamoun et al., 2006a) zurückführen ließe. Einen Doppelknockout, der diese Frage weiter klären könnte, gibt es jedoch bisher noch nicht. Im Rahmen dieser Arbeit wurde demonstriert, dass die N-terminalen Repressions-domänen, welche ein gemeinsames Merkmal von Klf10 und Klf11 darstellen, essentiell für die Klf11-vermittelten Effekte in Oli-neuZellen sind. Der Verlust dieser Domänen verhindert möglicherweise die Interaktion mit dem Ko-Repressor-Komplex mSin3A, welche durch Modifikation der Chromatin- 
struktur via Histon-Deacetylierung zum transkriptionellen ,silencing“ beiträgt. Obwohl es belegt ist, dass Klf10 und Klf11, abhängig von Zelltyp und untersuchtem Promotor, sowohl als transkriptionelle Repressoren als auch als Aktivatoren wirken können (Noti et al., 2004; Neve et al., 2005; Spittau et al., 2010), demonstrieren unsere Ergebnisse, dass die Klf11 vermittelte transkriptionelle Repression nötig ist, um die Caspase-3 und somit die Apoptose in Oli-neu Zellen zu aktivieren. Die Überexpression von Klf11 hat eine Steigerung der R-Smad-Aktivität zur Folge. Die R-Smads Smad2 und Smad3 werden nach der Bindung von TGF- $\beta$ an seine korrespondierenden Rezeptoren durch Phosphorylierung aktiviert (Abdollah et al., 1997). Es konnte nachgewiesen werden, dass nach Überexpression von Klf11 keine messbaren Mengen an zusätzlichem TGF- $\beta$ sezerniert wurden, was nahelegt, dass die TGF- $\beta$ abhängige Phosphorylierung nicht der einzige Mechanismus ist, der zu der beobachteten R-Smad-Aktivierung führen kann. Es ist erwiesen, dass humanes KLF10 und KLF11 in der Lage sind die Transkription des inhibitorischen SMAD7 zu hemmen (Johnsen et al., 2002; Ellenrieder et al., 2004). Diese Beobachtungen waren Anlass zu der Untersuchung, ob es in Oli-neu-Zellen nach Klf11-Überexpression einen ähnlichen Mechanismus gibt. Als Ergebnis dieser Untersuchungen konnte gezeigt werden, die Expession von Smad7 unterdrückt und die R-Smad-Aktivität steigert. Der Smad7-Promotor enthält verschiedene Sp1Bindungsstellen (Brodin et al., 2000). Mit Hilfe eines Sp1-bindungsstellen-defizienten Promotorkonstrukts konnte nachgewiesen werden, dass diese für die Klf11-vermittelte transkriptionelle Repression von Smad7 unerlässlich sind. Das Fehlen der N-terminalen Repressionsdomäne führte zu einem Verlust der Hemmung der Transkription durch den Wildtyp-Smad7-Promotor, womit bewiesen werden konnte, dass Smad7 ein Klf11Zielgen in Oli-neu-Zellen ist. Weiterhin geht die Klf11-vermittelte Apoptose mit der Aktivierung von NF-кB einher, welche ebenfalls vom Vorhandensein der N-terminalen Repressionsdomäne abhängig ist (Gohla et al., 2008b). Die Überexpression von Klf10 in Oli-neu Zellen führt zu einem Rückgang der NF-кB Expression (Bender et al., 2004). Eine mögliche Erklärung hierfür wäre, dass Klf10 und Klf11 die Apoptose in Oli-neu Zellen durch die Aktivierung unterschiedlicher pro-apoptotischer Signalwege induzieren. 


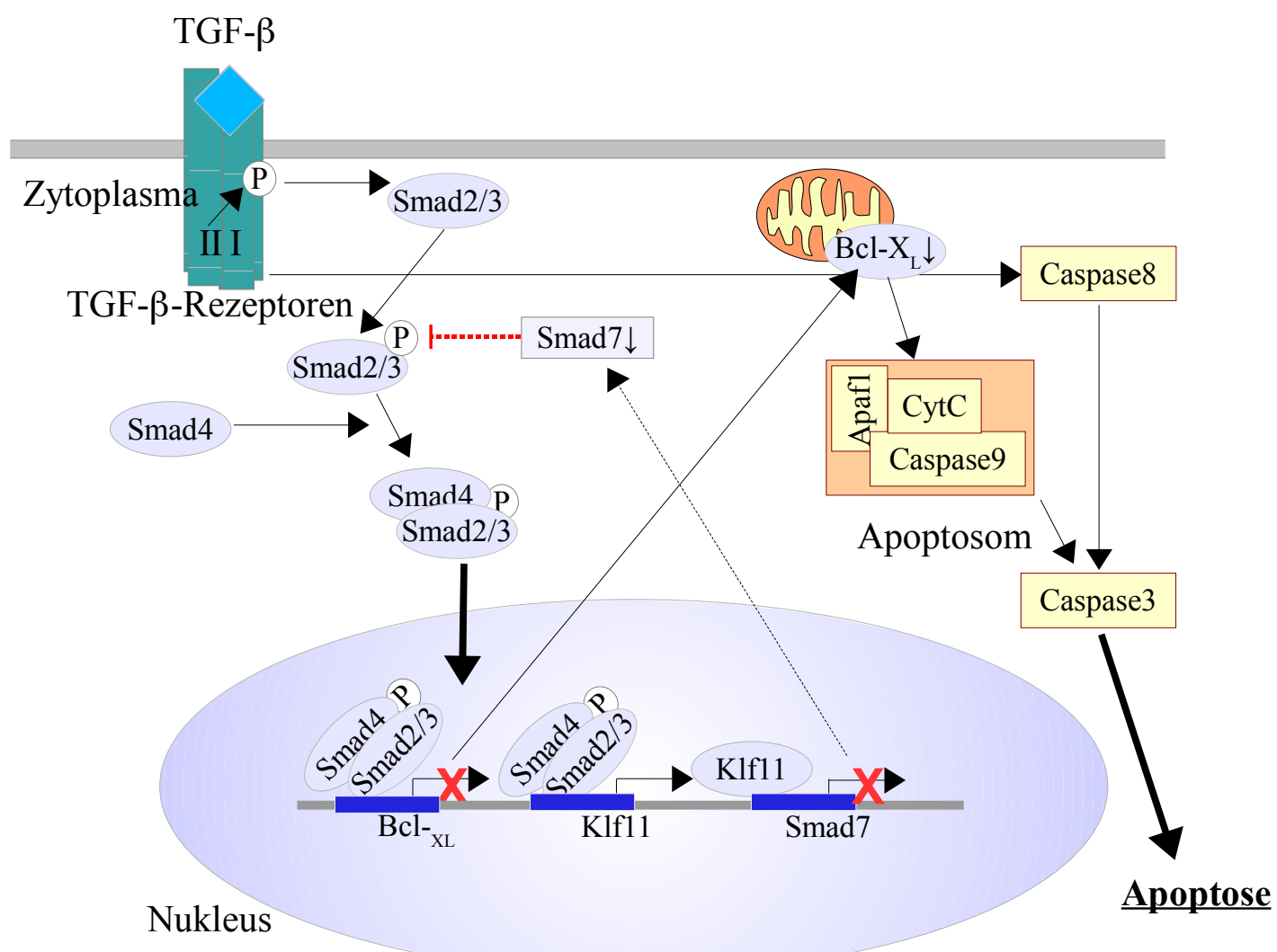

Abbildung 8: Die Rolle von Klf11 bei der TGF- $\beta$-vermittelten Apoptose

Um dies zu klären, wäre eine detaillierte Untersuchung der molekularbiologischen Mechanismen hinter diesem Phänomen nötig. Die funktionelle Rolle von Smad7 bei der TGF- $\beta$-induzierten Apoptose scheint zelltyp- bzw. gewebespezifisch zu sein. In BLymphozyten ist Smad7 hochreguliert, um die TGF- $\beta$ - und AktivinA- induzierte Apoptose zu hemmen (Ishisaki et al., 1998; Patil et al., 2000). Lallemand und Mitarbeiter fanden heraus, dass Smad7 in Ephithelzellen NF-кB hemmt und somit die TGF- $\beta$-vermittelte Apoptose potenziert (Lallemand et al., 2001). Im Gegensatz dazu induziert Smad7 diese in Mesangium- (Okado et al., 2002) und in Prostata-KarzinomZellen (Landström et al., 2000). Die Tatsache, dass Klf11 die Transkription von Smad7 hemmt und somit die Intensität und Dauer des TGF- $\beta$ Signals verstärkt, liefert möglicherweise einen wichtigen Hinweis für das Verständnis des Dialogs zwischen den verschiedenen Signalwegen. Lacmann und Kollegen konnten (2007) zeigen, dass Klf10 in hippokampalen Neuronenkulturen in Abhängigkeit von deren synaptischer Aktivität hochreguliert wird. Dieser Effekt wird durch eine aktivitätsabhängige TGF- $\beta$-Sekretion 
der Neuronen vermittelt. TGF- $\beta$ wirkt in diesem Szenario autokrin und aktiviert den TGF- $\beta$-Signalweg in den Neuronen (Lacmann et al., 2007).

Es ist mittlerweile erwiesen, dass die Induktion von Klf10 und Klf11 nicht auf TGF- $\beta$ beschränkt ist. Auch Östrogen (Tau et al., 1998), BMP2, BMP4, AktivinA (Hefferan et al., 2000b), CTGF (Wahab et al., 2005), GDNF (Yajima et al., 1997), NGF (Spittau et al., 2010) und andere Faktoren können Klf10 und/oder Klf11 induzieren und den TGF$\beta$-Signalweg auf eine Klf11-abhängige Weise beeinflussen.

\subsubsection{Die Expression und Regulation von Klf10 und Klf11 in PC12-Zellen}

In der vorliegenden Arbeit konnte gezeigt werden, dass sowohl Klf10 als auch Klf11 in PC12-Zellen exprimiert werden. Die Behandlung dieser Zellen mit NGF führt zu einer schnellen und anhaltenden Induktion von Klf10 auf mRNA- sowie auf Proteinebene. Mit Hilfe des Inhibitors K252a konnte gezeigt werden, dass diese Induktion TrkAabhängig ist. NGF steigert in PC12-Zellen die Sekretion von TGF- $\beta$ (unpublizierte Befunde von Farkas und Krieglstein). Um zu zeigen, dass die Regulation von Klf10 nicht durch TGF- $\beta$ beeinflusst war, wurde der TGF- $\beta$-RI mit Hilfe des Alk-Inhibitors SB431542 gehemmt. Dies hatte keinen Einfluss auf die Indukion von Klf10, wodurch eindeutig bewiesen werden konnte, dass diese NGF-vermittelt und TGF- $\beta$-unabhängig war. Im Gegensatz zur Induktion von Klf10 wurde die Klf11-mRNA nach der Behandlung mit NGF herrunterreguliert (Spittau et al., 2010). Die Regulation von Klf10 war dabei dosisabhängig, während die Regulation von Klf11 nicht von der NGFDosierung abhing. Dieses Ergebnis deutet darauf hin, dass NGF keinen direkten Effekt auf die Regulation von Klf11 hat. Bei Klf10 und Klf11 handelt es sich um sog. „,early response"de novo einer Vorbehandlung der PC12-Zellen mit dem Proteinsynthesehemmer Cycloheximid (CHX) war die Induktion von Klf10 durch NGF ebennstrukte kloniert und analysiert. Es konnte eine Region (-516 bis -219$)$ innerhalb der Klf10 5'-untranslatierten Region als NGF-responsiv identifiziert werden. Diese Region beinhaltet potenzielle Bindungsstellen für die Transkripionsfaktoren Sp1 und CREB, welche beide am NGF-Signalweg beteiligt sind. Eine Beteiligung von TrkA bei der Induktion von Klf10 wurde bereits 2005 von Wahab und ihren Mitarbeitern gezeigt, und Wibrand und Mitarbeiter erbrachten 2006 den Nachweis, dass die intrahippocampale Infusion von BDNF zum Anstieg des Klf10 mRNA-Levels im Gyrus dentatus der Ratte führt (Wahab et al., 2005; Wibrand et al., 2006). Auf Basis dieser 
Ergebnisse lag es nahe, die Regulation von Klf10 und Klf11 in PC12-Zellen zu analysieren, welche ein gängiges Modellsystem für die Untersuchung des NGFSignalweges, sowie ein Zellkultur-modell für die Untersuchung sympathischer Neurone darstellen (Greene und Tishler, 1976). PC12-Zellen besitzen nur sehr geringe Anteile des TGF- $\beta$-Rezeptor II und gelten daher im Allgemeinen als nicht-TGF- $\beta$-responsiv (Lutz et al., 2004). Sie sezernieren jedoch TGF- $\beta$ nach Behandlung mit NGF. Durch unsere Untersuchungen mit den Inhibitoren K252a und SB431542 konnte bewiesen werden, dass die Regulation von Klf10 TrkA- abhängig und TGF- $\beta$-unabhängig stattfindet. NGF bindet jedoch außer an TrkA auch an p75 NTR. Man kann zwar mit Sicherheit sagen, dass der TrkA-Rezeptor an der Induktion von Klf10 beteiligt ist, jedoch nicht eindeutig ausschließen, dass p75 involviert ist. In der Vergangenheit wurde gezeigt, dass unterschied-liche Transkriptionsfaktoren durch NGF posttranslational modifiziert werden, um die transkriptionelle Regulation der NGF-Zielgene zu vermitteln (Chao, 2003). Sp1 und CREB sind solche Faktoren, die potenziell in die Regulation von Klf10 involviert sein könnten. Beide Transkriptionsfaktoren werden durch die Phosphorylierung von NGF aktiviert (Billon et al., 1999; Vaudry et al., 2002) und es konnten potenzielle Bindungsstellen von Sp1 und CREB innerhalb eines NGF-responsiven Elementes der „5'-regulatory region“ von Klf10 nachgewiesen werden. Die NGF-abhängige Phosphorylierung von Sp1 und/oder CREB könnte somit das initiale Ereignis sein, das der Regulation von K1f10 in PC12-Zellen zugrunde liegt. Der genaue Mechanismus der NGF-vermittelten Regulation von Klf10 bleibt jedoch unklar und bedarf somit weitergehender Untersuchungen.

\subsubsection{Die Rolle von Klf10 bei der NGF-vermittelten Differenzierung}

Im Rahmen der vorliegenden Arbeit konnte gezeigt werden, dass die Überexpression von Klf10 das Fortschreiten des Zellzyklus abschwächt, d.h. die Anzahl der Zellen in der S-Phase waren nach Überexpression von Klf10 signifikant reduziert, außerdem konnte eine gesteigerte Expression des „Cycline-dependent Kinase-Inhibitors“ p21 nachgewiesen werden (Gohla et al., 2008a). Einen Einfluss auf die Differenzierung der PC12-Zellen hat Klf10 jedoch (Spittau et al., 2010). Es ist bekannt, dass p75 ${ }^{\mathrm{NTR}}$ an der

Regulation der Proliferation verschiedener Zelltypen, einschließlich Astrozyten (Cragnolini et al., 2009) und hepatischen Myofibroblasten (Kendall et al., 2009), 
beteiligt ist. Da Klf10 die Proliferation von PC12-Zellen hemmt, wäre es interessant die

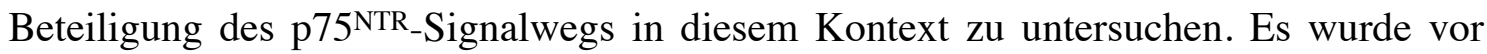
einiger Zeit berichtet, dass Klf10, hochreguliert durch BMP2 in Vorläufern der Körnerzellen des Kleinhirns, Zellzyklusarrest induzieren konnte, jedoch nicht in der Lage war, deren terminale Differenzierung zu induzieren (Alvarez-Rodríguez et al., 2007). Mit Hilfe der PC12 Zellen konnte ein ähnlicher Mechanismus für Klf10 im Zusammenhang mit der NGF-vermittelten Induktion von Zellzyklusarrest und Differenzierung nachgewiesen werden. Klf10 ist in der Lage, die Proliferation von PC12-Zellen zu hemmen, ohne gleichzeitig deren terminale Differenzierung zu initiieren (Spittau et al., 2010). Als Transkriptionsfaktor reguliert Klf10 möglicherweise Gene, die in die Zellzykluskontrolle von PC12-Zellen eingreifen, während für die Differenzierung dieser Zellen noch zusätzliche Gene benötigt werden. Die Zielgene von Klf10 im Kontext des NGF-vermittelten Zellzyklusarrests sowie der genaue Mechanismus verbleiben unbekannt und erfordern weitere Untersuchungen. 


\section{Literaturverzeichnis}

Abdollah, S., Macías-Silva, M., Tsukazaki, T., Hayashi, H., Attisano, L., \& Wrana, J. L. (1997). TbetaRI phosphorylation of Smad2 on Ser465 and Ser467 is required for Smad2-Smad4 complex formation and signaling. The Journal of Biological Chemistry, 272(44), 27678-27685.

Acehan, D., Jiang, X., Morgan, D. G., Heuser, J. E., Wang, X., \& Akey, C. W. (2002). Three-dimensional structure of the apoptosome: implications for assembly, procaspase-9 binding, and activation. Molecular Cell, 9(2), 423-432.

Alvarez-Rodríguez, R., Barzi, M., Berenguer, J., \& Pons, S. (2007). Bone morphogenetic protein 2 opposes Shh-mediated proliferation in cerebellar granule cells through a TIEG-1-based regulation of Nmyc. The Journal of Biological Chemistry, 282(51), 37170-37180.

Ashkenazi, A. (2002). Targeting death and decoy receptors of the tumour-necrosis factor superfamily. Nature Reviews. Cancer, 2(6), 420-430.

Barde, Y. A. (1990). The nerve growth factor family. Progress in Growth Factor Research, 2(4), 237-248.

Barker, P. A., \& Shooter, E. M. (1994). Disruption of NGF binding to the low affinity neurotrophin receptor p75LNTR reduces NGF binding to TrkA on PC12 cells. Neuron, 13(1), 203-215.

Beitner-Johnson, D., Werner, H., Roberts, C. T., Jr, \& LeRoith, D. (1995). Regulation of insulin-like growth factor I receptor gene expression by Sp1: physical and functional interactions of Sp1 at GC boxes and at a CT element. Molecular Endocrinology, 9(9), 1147-1156.

Bender, H., Wang, Z., Schuster, N., \& Krieglstein, K. (2004). TIEG1 facilitates transforming growth factor-beta-mediated apoptosis in the oligodendroglial cell line OLI-neu. Journal of Neuroscience Research, 75(3), 344-352.

Benedetti, M., Levi, A., \& Chao, M. V. (1993). Differential expression of nerve growth factor receptors leads to altered binding affinity and neurotrophin responsiveness. Proceedings of the National Academy of Sciences of the United States of America, 90(16), 7859-7863.

Bensamoun, S. F., Hawse, J. R., Subramaniam, M., Ilharreborde, B., Bassillais, A., Benhamou, C. L., Fraser, D. G., Oursler, M. J., Amadio, P. C., An, K.-N., \& Spelsberg, T. C. (2006a). TGFbeta inducible early gene-1 knockout mice display defects in bone strength and microarchitecture. Bone, 39(6), 1244-1251.

Bensamoun, S. F., Tsubone, T., Subramaniam, M., Hawse, J. R., Boumediene, E., Spelsberg, T. C., An, K.-N., \& Amadio, P. C. (2006b). Age-dependent changes in the mechanical properties of tail tendons in TGF-beta inducible early gene- 1 knockout mice. Journal of Applied Physiology, 101(5), 1419-1424. 
Berger, E. A., \& Shooter, E. M. (1977). Evidence for pro-beta-nerve growth factor, a biosynthetic precursor to beta-nerve growth factor. Proceedings of the National Academy of Sciences of the United States of America, 74(9), 3647-3651.

Bernardi, P., Scorrano, L., Colonna, R., Petronilli, V., \& Di Lisa, F. (1999). Mitochondria and cell death. Mechanistic aspects and methodological issues. European Journal of Biochemistry / FEBS, 264(3), 687-701.

Billon, N., Carlisi, D., Datto, M. B., van Grunsven, L. A., Watt, A., Wang, X. F., \& Rudkin, B. B. (1999). Cooperation of Sp1 and p300 in the induction of the CDK inhibitor p21WAF1/CIP1 during NGF-mediated neuronal differentiation. Oncogene, $18(18), 2872-2882$.

Birnbaum, M. J., van Wijnen, A. J., Odgren, P. R., Last, T. J., Suske, G., Stein, G. S., \& Stein, J. L. (1995). Sp1 trans-activation of cell cycle regulated promoters is selectively repressed by Sp3. Biochemistry, 34(50), 16503-16508.

Bouwman, P., \& Philipsen, S. (2002). Regulation of the activity of Sp1-related transcription factors. Molecular and Cellular Endocrinology, 195(1-2), 27-38.

Brodin, G., Ahgren, A., ten Dijke, P., Heldin, C. H., \& Heuchel, R. (2000). Efficient TGF-beta induction of the Smad7 gene requires cooperation between AP-1, Sp1, and Smad proteins on the mouse Smad7 promoter. The Journal of Biological Chemistry, 275(37), 29023-29030.

Buck, A., Buchholz, M., Wagner, M., Adler, G., Gress, T., \& Ellenrieder, V. (2006). The tumor suppressor KLF11 mediates a novel mechanism in transforming growth factor beta-induced growth inhibition that is inactivated in pancreatic cancer. Molecular Cancer Research: $M C R, 4(11), 861-872$.

Chalaux, E., López-Rovira, T., Rosa, J. L., Pons, G., Boxer, L. M., Bartrons, R., \& Ventura, F. (1999). A zinc-finger transcription factor induced by TGF-beta promotes apoptotic cell death in epithelial Mv1Lu cells. FEBS Letters, 457(3), 478-482.

Chao, M. V. (2003). Neurotrophins and their receptors: a convergence point for many signalling pathways. Nature Reviews. Neuroscience, 4(4), 299-309.

Chao, M. V., Bothwell, M. A., Ross, A. H., Koprowski, H., Lanahan, A. A., Buck, C. R., $\&$ Sehgal, A. (1986). Gene transfer and molecular cloning of the human NGF receptor. Science (New York, N.Y.), 232(4749), 518-521.

Cook, T., \& Urrutia, R. (2000). TIEG proteins join the Smads as TGF-beta-regulated transcription factors that control pancreatic cell growth. American Journal of Physiology. Gastrointestinal and Liver Physiology, 278(4), G513-521.

Cook, T, Gebelein, B., Belal, M., Mesa, K., \& Urrutia, R. (1999). Three conserved transcriptional repressor domains are a defining feature of the TIEG subfamily of Sp1like zinc finger proteins. The Journal of Biological Chemistry, 274(41), 29500-29504. 
Cook, T, Gebelein, B., Mesa, K., Mladek, A., \& Urrutia, R. (1998). Molecular cloning and characterization of TIEG2 reveals a new subfamily of transforming growth factorbeta-inducible Sp1-like zinc finger-encoding genes involved in the regulation of cell growth. The Journal of Biological Chemistry, 273(40), 25929-25936.

Cragnolini, A. B., Huang, Y., Gokina, P., \& Friedman, W. J. (2009). Nerve growth factor attenuates proliferation of astrocytes via the p75 neurotrophin receptor. Glia, 57(13), 1386-1392.

Dechant, G., \& Barde, Y. A. (1997). Signalling through the neurotrophin receptor p75NTR. Current Opinion in Neurobiology, 7(3), 413-418.

Dennler, S., Goumans, M.-J., \& ten Dijke, P. (2002). Transforming growth factor beta signal transduction. Journal of Leukocyte Biology, 71(5), 731-740.

Derynck, R., \& Feng, X. H. (1997). TGF-beta receptor signaling. Biochimica Et Biophysica Acta, 1333(2), F105-150.

Derynck, R., \& Zhang, Y. E. (2003). Smad-dependent and Smad-independent pathways in TGF-beta family signalling. Nature, 425(6958), 577-584.

Dynan, W. S., \& Tjian, R. (1983). Isolation of transcription factors that discriminate between different promoters recognized by RNA polymerase II. Cell, 32(3), 669-680.

Ellenrieder, V., Buck, A., Harth, A., Jungert, K., Buchholz, M., Adler, G., Urrutia, R., \& Gress, T. M. (2004). KLF11 mediates a critical mechanism in TGF-beta signaling that is inactivated by Erk-MAPK in pancreatic cancer cells. Gastroenterology, 127(2), 607-620.

Fautsch, M. P., Vrabel, A., Subramaniam, M, Hefferen, T. E., Spelsberg, T. C., \& Wieben, E. D. (1998). TGFbeta-inducible early gene (TIEG) also codes for early growth response alpha (EGRalpha): evidence of multiple transcripts from alternate promoters. Genomics, 51(3), 408-416.

Fernandez-Zapico, M. E., van Velkinburgh, J. C., Gutiérrez-Aguilar, R., Neve, B., Froguel, P., Urrutia, R., \& Stein, R. (2009). MODY7 gene, KLF11, is a novel p300dependent regulator of Pdx-1 (MODY4) transcription in pancreatic islet beta cells. The Journal of Biological Chemistry, 284(52), 36482-36490.

Frazier, W. A., Boyd, L. F., \& Bradshaw, R. A. (1973). Interaction of nerve growth factor with surface membranes: biological competence of insolubilized nerve growth factor. Proceedings of the National Academy of Sciences of the United States of America, 70(10), 2931-2935.

Gebelein, B., Fernandez-Zapico, M., Imoto, M., \& Urrutia, R. (1998). KRABindependent suppression of neoplastic cell growth by the novel zinc finger transcription factor KS1. Journal of Clinical Investigation, 102(11), 1911-1919. 
Geiser, A. G., Busam, K. J., Kim, S. J., Lafyatis, R., O’Reilly, M. A., Webbink, R., Roberts, A. B., u. a. (1993). Regulation of the transforming growth factor-beta 1 and beta 3 promoters by transcription factor Sp1. Gene, 129(2), 223-228.

van Ginkel, F. W., Wahl, S. M., Kearney, J. F., Kweon, M. N., Fujihashi, K., Burrows, P. D., Kiyono, H., u. a. (1999). Partial IgA-deficiency with increased Th2-type cytokines in TGF-beta 1 knockout mice. Journal of Immunology (Baltimore, Md.: 1950), 163(4), 1951-1957.

Gohla, G., Spittau, B., Behrendt, M. and Krieglstein K. (2008a). Tieg1/Klf10 contributes to NGF-mediated cell cycle arrest of PC12 cells by regulation od p21. Poster Abstract Booklet 103rd Annual Meeting, Innsbruck 2008, 167.

Gohla, G., Krieglstein, K., \& Spittau, B. (2008b). Tieg3/Klf11 induces apoptosis in OLI-neu cells and enhances the TGF-beta signaling pathway by transcriptional repression of Smad7. Journal of Cellular Biochemistry, 104(3), 850-861.

www.anatomische-gesellschaft.de/annual-meetings/abstract-archive.html (aufgerufen $\underline{\operatorname{am} 08.09 .2011)}$

Gomperts, B. D., Kramer, I. M. \& Tatham, P. E. R. (2003). Signal Transduction. Verlag Elsevier Academic Press, First published as a paperback edition, London 2003.

Greene, L. A. (1978). Nerve growth factor prevents the death and stimulates the neuronal differentiation of clonal PC12 pheochromocytoma cells in serum-free medium. The Journal of Cell Biology, 78(3), 747-755.

Greene, L. A., \& Tischler, A. S. (1976). Establishment of a noradrenergic clonal line of rat adrenal pheochromocytoma cells which respond to nerve growth factor. Proceedings of the National Academy of Sciences of the United States of America, 73(7), 2424-2428.

Greene, L. A., Shooter, E. M., \& Varon, S. (1969). Subunit interaction and enzymatic activity of mouse 7S nerve growth factor. Biochemistry, 8(9), 3735-3741.

Guillaumond, F., Gréchez-Cassiau, A., Subramaniam, M., Brangolo, S., PeteriBrünback, B., Staels, B., u. a. (2010). Kruppel-like factor KLF10 is a link between the circadian clock and metabolism in liver. Molecular and Cellular Biology, 30(12), 3059-3070.

Hefferan, T. E., Reinholz, G. G., Rickard, D J, Johnsen, S A, Waters, K. M., Subramaniam, M, \& Spelsberg, T. C. (2000a). Overexpression of a nuclear protein, TIEG, mimics transforming growth factor-beta action in human osteoblast cells. The Journal of Biological Chemistry, 275(27), 20255-20259.

Hefferan, T. E., Subramaniam, M, Khosla, S, Riggs, B. L., \& Spelsberg, T. C. (2000b). Cytokine-specific induction of the TGF-beta inducible early gene (TIEG): regulation by specific members of the TGF-beta family. Journal of Cellular Biochemistry, 78(3), 380-390. 
Hempstead, B. L., Martin-Zanca, D., Kaplan, D. R., Parada, L. F., \& Chao, M. V. (1991). High-affinity NGF binding requires coexpression of the trk proto-oncogene and the low-affinity NGF receptor. Nature, 350(6320), 678-683.

Hengartner, M. O. (2000). The biochemistry of apoptosis. Nature, 407(6805), 770-776.

Huang, E. J., \& Reichardt, L. F. (2001). Neurotrophins: roles in neuronal development and function. Annual Review of Neuroscience, 24, 677-736.

Huang, E. J., \& Reichardt, L. F. (2003). Trk receptors: roles in neuronal signal transduction. Annual Review of Biochemistry, 72, 609-642.

Imamura, T., Takase, M., Nishihara, A., Oeda, E., Hanai, J., Kawabata, M., \& Miyazono, K. (1997). Smad6 inhibits signalling by the TGF-beta superfamily. Nature, $389(6651), 622-626$.

Ishii, S., Kadonaga, J. T., Tjian, R., Brady, J. N., Merlino, G. T., \& Pastan, I. (1986). Binding of the Sp1 transcription factor by the human Harvey ras1 proto-oncogene promoter. Science, 232(4756), 1410-1413.

Ishisaki, A., Yamato, K., Nakao, A., Nonaka, K., Ohguchi, M., ten Dijke, P., \& Nishihara, T. (1998). Smad7 is an Aktivin-inducible inhibitor of Aktivin-induced growth arrest and apoptosis in mouse B cells. The Journal of Biological Chemistry, 273(38), 24293-24296.

Jin, W., Di, G., Li, J., Chen, Y., Li, W., Wu, J., Cheng, T., u. a. (2007). TIEG1 induces apoptosis through mitochondrial apoptotic pathway and promotes apoptosis induced by homoharringtonine and velcade. FEBS Letters, 581(20), 3826-3832.

Johnsen, S. A., Subramaniam, M., Katagiri, T., Janknecht, R., \& Spelsberg, T. C. (2002). Transcriptional regulation of Smad2 is required for enhancement of TGFbeta/Smad signaling by TGFbeta inducible early gene. Journal of Cellular Biochemistry, 87(2), 233-241.

Jung, M., Krämer, E. M., Müller, T., Antonicek, H., \& Trotter, J. (1998). Novel pluripotential neural progenitor lines exhibiting rapid controlled differentiation to neurotransmitter receptor-expressing neurons and glia. The European Journal of Neuroscience, 10(10), 3246-3256.

Kaczynski, J., Cook, T., \& Urrutia, R. (2003). Sp1- and Krüppel-like transcription factors. Genome Biology, 4(2), 206.

Kadonaga, J. T., Carner, K. R., Masiarz, F. R., \& Tjian, R. (1987). Isolation of cDNA encoding transcription factor Sp1 and functional analysis of the DNA binding domain. Cell, 51(6), 1079-1090.

Kaufmann, S. H., \& Earnshaw, W. C. (2000). Induction of apoptosis by cancer chemotherapy. Experimental Cell Research, 256(1), 42-49. 
Kendall, T. J., Hennedige, S., Aucott, R. L., Hartland, S. N., Vernon, M. A., Benyon, R. C., \& Iredale, J. P. (2009). p75 Neurotrophin receptor signaling regulates hepatic myofibroblast proliferation and apoptosis in recovery from rodent liver fibrosis. Hepatology, 49(3), 901-910.

Lacmann, A., Hess, D., Gohla, G., Roussa, E., \& Krieglstein, K. (2007). Activitydependent release of transforming growth factor-beta in a neuronal network in vitro. Neuroscience, 150(3), 647-657.

Lallemand, F., Mazars, A., Prunier, C., Bertrand, F., Kornprost, M., Gallea, S., RomanRoman, S., u. a. (2001). Smad7 inhibits the survival nuclear factor kappaB and potentiates apoptosis in epithelial cells. Oncogene, 20(7), 879-884.

Landström, M., Heldin, N. E., Bu, S., Hermansson, A., Itoh, S., ten Dijke, P., \& Heldin, C. H. (2000). Smad7 mediates apoptosis induced by transforming growth factor beta in prostatic carcinoma cells. Current Biology: $C B, 10(9), 535-538$.

Levi-Montalcini, R. (1987). The nerve growth factor 35 years later. Science, 237(4819), 1154-1162.

Li, L. Y., Luo, X., \& Wang, X. (2001). Endonuclease G is an apoptotic DNase when released from mitochondria. Nature, 412(6842), 95-99.

Liu, J.-W., Almaguel, F. G., Bu, L., De Leon, D. D., \& De Leon, M. (2008). Expression of E-FABP in PC12 Cells Increases Neurite Extension during Differentiation: Involvement of n-3 and n-6 Fatty Acids. Journal of Neurochemistry, 106(5), 2015-2029.

Lockshin R.A. \& Williams C.M. (1964). Programmed cell death. II. Endocrine potentiation of the breakdown of the intersegmental muscles of silkmoths. Journal of Insect Physiology, 10, 643-649.

Loeffler, M., \& Kroemer, G. (2000). The mitochondrion in cell death control: certainties and incognita. Experimental Cell Research, 256(1), 19-26.

Lu, B., Pang, P.T., \& Woo, N. H. (2005). The yin and yang of neurotrophin action. Nature Reviews. Neuroscience, 6(8), 603-614.

Luo, X., Budihardjo, I., Zou, H., Slaughter, C., \& Wang, X. (1998). Bid, a Bcl2 interacting protein, mediates cytochrome c release from mitochondria in response to activation of cell surface death receptors. Cell, 94(4), 481-490.

Lutz, M., Krieglstein, K., Schmitt, S., ten Dijke, P., Sebald, W., Wizenmann, A., \& Knaus, P. (2004). Nerve growth factor mediates activation of the Smad pathway in PC12 cells. European Journal of Biochemistry / FEBS, 271(5), 920-931.

Martin-Zanca, D., Oskam, R., Mitra, G., Copeland, T., \& Barbacid, M. (1989). Molecular and biochemical characterization of the human trk proto-oncogene. Molecular and Cellular Biology, 9(1), 24-33. 
Massagué, J. (1990). The transforming growth factor-beta family. Annual Review of Cell Biology, 6, 597-641.

Massagué, J. (1998). TGF-beta signal transduction. Annual Review of Biochemistry, 67, 753-791.

Miller, F. D., \& Kaplan, D. R. (2001). On Trk for retrograde signaling. Neuron, 32(5), 767-770.

Miller, J., McLachlan, A. D., \& Klug, A. (1985). Repetitive zinc-binding domains in the protein transcription factor IIIA from Xenopus oocytes. The EMBO Journal, 4(6), 1609-1614.

Mitsumoto, M., Mitsumoto, A., \& Demple, B. (2003). Nitric oxide-mediated upregulation of the TGF-beta-inducible early response gene-1 (TIEG1) in human fibroblasts by mRNA stabilization independent of TGF-beta. Free Radical Biology \& Medicine, 34(12), 1607-1613.

Moustakas, A., \& Kardassis, D. (1998). Regulation of the human p21/WAF1/Cip1 promoter in hepatic cells by functional interactions between Sp1 and Smad family members. Proceedings of the National Academy of Sciences of the United States of America, 95(12), 6733-6738.

Naismith, J. H., \& Sprang, S. R. (1998). Modularity in the TNF-receptor family. Trends in Biochemical Sciences, 23(2), 74-79.

Nakao, A., Afrakhte, M., Morén, A., Nakayama, T., Christian, J. L., Heuchel, R., Itoh, S., u. a. (1997). Identification of Smad7, a TGFbeta-inducible antagonist of TGF-beta signalling. Nature, 389(6651), 631-635.

Neve, B., Fernandez-Zapico, M. E., Ashkenazi-Katalan, V., Dina, C., Hamid, Y. H., Joly, E., Vaillant, E., u. a. (2005). Role of transcription factor KLF11 and its diabetesassociated gene variants in pancreatic beta cell function. Proceedings of the National Academy of Sciences of the United States of America, 102(13), 4807-4812.

Noti, J. D., Johnson, A. K., \& Dillon, J. D. (2004). The zinc finger transcription factor transforming growth factor beta-inducible early gene-1 confers myeloid-specific activation of the leukocyte integrin CD11d promoter. The Journal of Biological Chemistry, 279(26), 26948-26958.

Nykjaer, A., Lee, R., Teng, K. K., Jansen, P., Madsen, P., Nielsen, M. S., Jacobsen, C., u. a. (2004). Sortilin is essential for proNGF-induced neuronal cell death. Nature, 427(6977), 843-848.

Okado, T., Terada, Y., Tanaka, H., Inoshita, S., Nakao, Atsuhito, \& Sasaki, S. (2002). Smad7 mediates transforming growth factor-beta-induced apoptosis in mesangial cells. Kidney International, 62(4), 1178-1186.

Oppenheim, R. W. (1991). Cell death during development of the nervous system. Annual Review of Neuroscience, 14, 453-501. 
Patapoutian, A., \& Reichardt, L. F. (2001). Trk receptors: mediators of neurotrophin action. Current Opinion in Neurobiology, 11(3), 272-280.

Patil, S., Wildey, G. M., Brown, T. L., Choy, L., Derynck, R., \& Howe, P. H. (2000). Smad7 is induced by CD40 and protects WEHI 231 B-lymphocytes from transforming growth factor-beta -induced growth inhibition and apoptosis. The Journal of Biological Chemistry, 275(49), 38363-38370.

Philipsen, S., \& Suske, G. (1999). A tale of three fingers: the family of mammalian Sp/ XKLF transcription factors. Nucleic Acids Research, 27(15), 2991-3000.

Prowse, D. M., Bolgan, L., Molnár, A., \& Dotto, G. P. (1997). Involvement of the Sp3 transcription factor in induction of $\mathrm{p} 21 \mathrm{Cip} 1 / \mathrm{WAF} 1$ in keratinocyte differentiation. The Journal of Biological Chemistry, 272(2), 1308-1314.

Rabizadeh, S., Oh, J., Zhong, L. T., Yang, J., Bitler, C. M., Butcher, L. L., \& Bredesen, D. E. (1993). Induction of apoptosis by the low-affinity NGF receptor. Science (New York, N.Y.), 261(5119), 345-348.

Rajamannan, N. M, Subramaniam, M., Abraham, T. P., Vasile, V. C., Ackerman, M. J., Monroe, D. G., Chew, T.-L., u. a. (2007). TGFbeta inducible early gene-1 (TIEG1) and cardiac hypertrophy: Discovery and characterization of a novel signaling pathway. Journal of Cellular Biochemistry, 100(2), 315-25.

Ribeiro, A., Bronk, S. F., Roberts, P. J., Urrutia, R., \& Gores, G. J. (1999). The transforming growth factor beta(1)-inducible transcription factor TIEG1, mediates apoptosis through oxidative stress. Hepatology, 30(6), 1490-1497.

Roberts, A. B., Anzano, M. A., Lamb, L. C., Smith, J. M., \& Sporn, M. B. (1981). New class of transforming growth factors potentiated by epidermal growth factor: isolation from non-neoplastic tissues. Proceedings of the National Academy of Sciences of the United States of America, 78(9), 5339-5343.

Roberts, A. B., \& Sporn, M. B. (1989). Regulation of endothelial cell growth, architecture, and matrix synthesis by TGF-beta. The American Review of Respiratory Disease, 140(4), 1126-1128.

Schuster, N., Bender, H., Philippi, A., Subramaniam, S., Strelau, J., Wang, Z., \& Krieglstein, K. (2002). TGF-beta induces cell death in the oligodendroglial cell line OLI-neu. Glia, 40(1), 95-108.

Schuster, N., \& Krieglstein, K. (2002). Mechanisms of TGF-beta-mediated apoptosis. Cell and Tissue Research, 307(1), 1-14.

Scott, J., Selby, M., Urdea, M., Quiroga, M., Bell, G. I., \& Rutter, W. J. (1983). Isolation and nucleotide sequence of a cDNA encoding the precursor of mouse nerve growth factor. Nature, 302(5908), 538-540.

Slee, E. A., Harte, M. T., Kluck, R. M., Wolf, B. B., Casiano, C. A., Newmeyer, D. D., Wang, H. G., u. a. (1999). Ordering the cytochrome c-initiated caspase cascade: 
hierarchical activation of caspases-2, -3, -6, -7, -8, and -10 in a caspase-9-dependent manner. The Journal of Cell Biology, 144(2), 281-292.

Song, C.-Z., Gavriilidis, G., Asano, H., \& Stamatoyannopoulos, G. (2005). Functional study of transcription factor KLF11 by targeted gene inactivation. Blood Cells, Molecules \& Diseases, 34(1), 53-59.

Souchelnytskyi, S., Tamaki, K., Engström, U., Wernstedt, C., ten Dijke, P., \& Heldin, C. H. (1997). Phosphorylation of Ser465 and Ser467 in the C terminus of Smad 2 mediates interaction with Smad4 and is required for transforming growth factor-beta signaling. The Journal of Biological Chemistry, 272(44), 28107-28115.

Spittau, B., \& Krieglstein, K. (2012). Klf10 and Klf11 as mediators of TGF-beta superfamily signaling. Cell and Tissue Research. DOI: 10.1007/S00441-011-1186-6

Spittau, B., Wang, Z., Boinska, D., \& Krieglstein, K. (2007). Functional domains of the TGF-beta-inducible transcription factor Tieg3 and detection of two putative nuclear localization signals within the zinc finger DNA-binding domain. Journal of Cellular Biochemistry, 101(3), 712-722.

Spittau, G., Happel, N., Behrendt, M., Chao, T. I., Krieglstein, K., \& Spittau, B. (2010). Tieg1/Klf10 is upregulated by NGF and attenuates cell cycle progression in the pheochromocytoma cell line PC12. Journal of Neuroscience Research, 88(9), 2017-2025.

Stach, R. W., \& Shooter, E. M. (1974). The biological activity of cross-linked beta nerve growth factor protein. The Journal of Biological Chemistry, 249(20), 6668-6674.

Subramaniam, M., Harris, S. A., Oursler, M. J., Rasmussen, K., Riggs, B. L., \& Spelsberg, T. C. (1995). Identification of a novel TGF-beta-regulated gene encoding a putative zinc finger protein in human osteoblasts. Nucleic Acids Research, 23(23), 4907-4912.

Subramaniam, M., Gorny, G., Johnsen, S. A., Monroe, D. G., Evans, G. L., Fraser, D. G., Rickard, D. J., u. a. (2005). TIEG1 null mouse-derived osteoblasts are defective in mineralization and in support of osteoclast differentiation in vitro. Molecular and Cellular Biology, 25(3), 1191-1199.

Susin, S. A., Lorenzo, H. K., Zamzami, N., Marzo, I., Snow, B. E., Brothers, G. M., Mangion, J., u. a. (1999). Molecular characterization of mitochondrial apoptosisinducing factor. Nature, 397(6718), 441-446.

Tachibana, I., Imoto, M., Adjei, P. N., Gores, G. J., Subramaniam, M, Spelsberg, T C, \& Urrutia, R. (1997). Overexpression of the TGFbeta-regulated zinc finger encoding gene, TIEG, induces apoptosis in pancreatic epithelial cells. The Journal of Clinical Investigation, 99(10), 2365-2374.

Tau, K. R., Hefferan, T. E., Waters, K. M., Robinson, J. A., Subramaniam, M., Riggs, B. L., \& Spelsberg, T. C. (1998). Estrogen regulation of a transforming growth factor-beta 
inducible early gene that inhibits deoxyribonucleic acid synthesis in human osteoblasts. Endocrinology, 139(3), 1346-1353.

Tischler, A. S., \& Greene, L. A. (1975). Nerve growth factor-induced process formation by cultured rat pheochromocytoma cells. Nature, 258(5533), 341-342.

Ullrich, A., Gray, A., Berman, C., Coussens, L., \& Dull, T. J. (1983). Sequence homology of human and mouse beta-NGF subunit genes. Cold Spring Harbor Symposia on Quantitative Biology, 48 Pt 1,435-442.

Vaudry, D., Stork, P. J. S., Lazarovici, P., \& Eiden, L. E. (2002). Signaling pathways for PC12 cell differentiation: making the right connections. Science (New York, N.Y.), 296(5573), 1648-1649.

Verhagen, A. M., Ekert, P. G., Pakusch, M., Silke, J., Connolly, L. M., Reid, G. E., Moritz, R. L., u. a. (2000). Identification of DIABLO, a mammalian protein that promotes apoptosis by binding to and antagonizing IAP proteins. Cell, 102(1), 43-53.

Wahab, N. A., Weston, B. S., \& Mason, R. M. (2005). Modulation of the TGFbeta/Smad signaling pathway in mesangial cells by CTGF/CCN2. Experimental Cell Research, 307(2), 305-314.

Wang, X. (2001). The expanding role of mitochondria in apoptosis. Genes \& Development, 15(22), 2922-2933.

Wang, Z., Peters, B., Klussmann, S., Bender, H., Herb, A., \& Krieglstein, K. (2004). Gene structure and evolution of Tieg3, a new member of the Tieg family of proteins. Gene, 325, 25-34.

Wharton, K., \& Derynck, R. (2009). TGFbeta family signaling: novel insights in development and disease. Development, 136(22), 3691-3697.

Wibrand, K., Messaoudi, E., Håvik, B., Steenslid, V., Løvlie, R., Steen, V. M., \& Bramham, C. R. (2006). Identification of genes co-upregulated with Arc during BDNFinduced long-term potentiation in adult rat dentate gyrus in vivo. The European Journal of Neuroscience, 23(6), 1501-1511.

Windisch, J. M., Auer, B., Marksteiner, R., Lang, M. E., \& Schneider, R. (1995). Specific neurotrophin binding to leucine-rich motif peptides of TrkA and TrkB. FEBS Letters, 374(1), 125-129.

Wrana, J. L., Attisano, L., Wieser, R., Ventura, F., \& Massagué, J. (1994). Mechanism of activation of the TGF-beta receptor. Nature, 370(6488), 341-347.

Yajima, S., Lammers, C. H., Lee, S. H., Hara, Y., Mizuno, K., \& Mouradian, M. M. (1997). Cloning and characterization of murine glial cell-derived neurotrophic factor inducible transcription factor (MGIF). The Journal of Neuroscience: The Official Journal of the Society for Neuroscience, 17(22), 8657-8666. 
Yoon, S. O., Casaccia-Bonnefil, P., Carter, B., \& Chao, M. V. (1998). Competitive signaling between TrkA and p75 nerve growth factor receptors determines cell survival. The Journal of Neuroscience: The Official Journal of the Society for Neuroscience, 18(9), 3273-3281.

Zhang, J. S., Moncrieffe, M. C., Kaczynski, J., Ellenrieder, V., Prendergast, F. G., \& Urrutia, R. (2001). A conserved alpha-helical motif mediates the interaction of Sp1-like transcriptional repressors with the corepressor mSin3A. Molecular and Cellular Biology, 21(15), 5041-5049.

Zhang, Y., \& Lin, S. C. (1997). Molecular characterization of the cyclin-dependent kinase inhibitor p27 promoter. Biochimica Et Biophysica Acta, 1353(3), 307-317. 


\section{Abstract}

The TGF- $\beta 1 /$ Klf-family of transcription factors. They play important roles in development and maintenance of various tissues and cell types.

The publications consolidated in this thesis describe, that Klf11 mimics TGF- $\beta$ effects by inducing apoptotsis accompanied by activation of cysteine-dependent aspartatespecific protease 3 (Caspase-3). Further the thesis demonstrates that Klf11 represses the expression of the inhibitory Sma and Mad related protein $7(\operatorname{Smad} 7)$ and disrupts the negative-feedback loop of the TGF- $\beta$ signaling pathway. Loss of the $\mathrm{N}$-terminal repression domains of Klf11 abrogates its proapoptotic nature and the repression of Smad7. In conclusion, the evidence was given that the transcription factor Klf11 is a downstream mediator of TGF- $\beta$-induced apoptosis and a potent modulator of the TGF- $\beta$ signaling pathway in the oligodendroglial cell line Oli-neu.

In a second part of this thesis it has been shown by using semiquantitative PCR and immunoblotting, that nerve growth factor (NGF), a member of the neurotrophin family, regulates the expression of Klf10 in the pheochromocytoma cell line PC12 in a tropomyosin related kinase A- (TrkA) dependent manner. Moreover, the thesis provides evidence for the existence of NGF-responsive elements in the $5^{\prime}$-regulatory region of Klf10, that contain binding sites for the transcription factors specificity protein 1 (Sp1) and cAMP response-element binding protein (CREB). After treatment with NGF, PC12 cells discontinue cell cycle progression and start to differentiate into a neuron-like phenotype. Using flow cytometry and differentiation assays it could be demonstrated that overexpression of Klf10 reduces cell cycle progression in PC12 cells but does not promote their terminal differentiation. Further, the experiments showed, that the reduced cell cycle progression is associated with an upregulation of the cycline dependent kinase inhibitor p21 at mRNA and protein levels. These results identify Klf10 as a NGF target gene and confirm its antiproliferative function in NGF signaling pathway in PC12 cells. Taken together, this thesis reveals that Klf10 and Klf11 are involved in two important developmental mechanisms: TGF- $\beta$-mediated apoptosis and NGF-mediated cell cycle arrest in cells of neural origin. 


\section{Zusammenfassung}

Die Proteine „Krüppel-like factor 10“ (Klf10) und „Krüppel-like factor 11“ (Klf11) bilden gemeinsam eine Unterfamilie innerhalb der Familie der Sp1-/Krüppelähnlichen Transkriptionsfaktoren. Sie spielen eine wichtige Rolle bei der Entwicklung und Erhaltung unterschiedlicher Gewebe und Zelltypen.

Für die vorliegende Arbeit wurde mit Hilfe der oligodendroglialen Zelllinie Oli-neu die Rolle von Klf11 im „Transforming growth factor- $\beta$-“ (TGF- $\beta$ ) Signalweg analysiert. Es konnte gezeigt werden, dass Klf11 in Oli-neu Zellen TGF- $\beta$-Effekte imitiert, indem es Apoptose induziert und gleichzeitig die „cystein-dependent aspartate-specific protease 3“ (Caspase3) aktiviert. Weiterhin wurde demonstriert, dass Klf11 den TGF- $\beta$ Signalweg durch transkriptionelle Hemmung des „Sma and Mad related protein 7“ verstärkt und somit die negative Rückkopplung des TGF- $\beta$-Signalwegs unterbricht. Der Verlust der N-terminalen Repressionsdomäne verhindert die proapoptotische Wirkung und die Hemmung von Smad7 durch Klf11. Zusammenfassend kann man sagen, dass es sich bei Klf11 um einen „Downstream“-Vermittler der TGF- $\beta$-induzierten Apoptose in Oli-neu Zellen handelt.

Im zweiten Teil der Arbeit wurde mittels semiquantitativer PCR und Immunoblots bewiesen, dass der „Nerve growth factor“ NGF die Transkription von Klf10 in der Phäochromozytomzelllinie PC12 in einer „tropomyosin related kinase A“- (TrkA) abhängigen Weise reguliert. Darüber hinaus konnte der Nachweis NGF-responsiver Elemente in der 5'-regulatorischen Region von Klf10, die Bindungsstellen für die Transkriptionsfaktoren „specificity protein 1“ (Sp1) und „cAMP response-element binding protein" (CREB) enthalten, erbracht werden. Ferner konnte bewiesen werden, dass Klf10 durch NGF in der Zelllinie PC12 sowohl auf transkriptioneller als auch auf translationeller Ebene reguliert wird. Nach Überexpression von Klf10 zeigte sich, dass Klf10 zwar eine antiproliferative Wirkung, jedoch keinen Einfluss auf die Differenzierung der Zellen hat. Weiterhin wurde gezeigt, dass die antiproliferative Wirkung mit einer gesteigerten Expression des „cycline-dependent kinase inhibitors“ p21 einhergeht. Zusammenfassend konnte in dieser Arbeit gezeigt werden, dass Klf10 und Klf11 an der Vermittlung wichtiger Mechanismen bei der Entwicklung des Nervensystems beteiligt sind: Der TGF- $\beta$-induzierten Apoptose und dem NGF-induzierten Zellzyklusarrest in Zellen neuralen Ursprungs. 
6 Anhang 